DIW BERLIN

Discussion

Papers
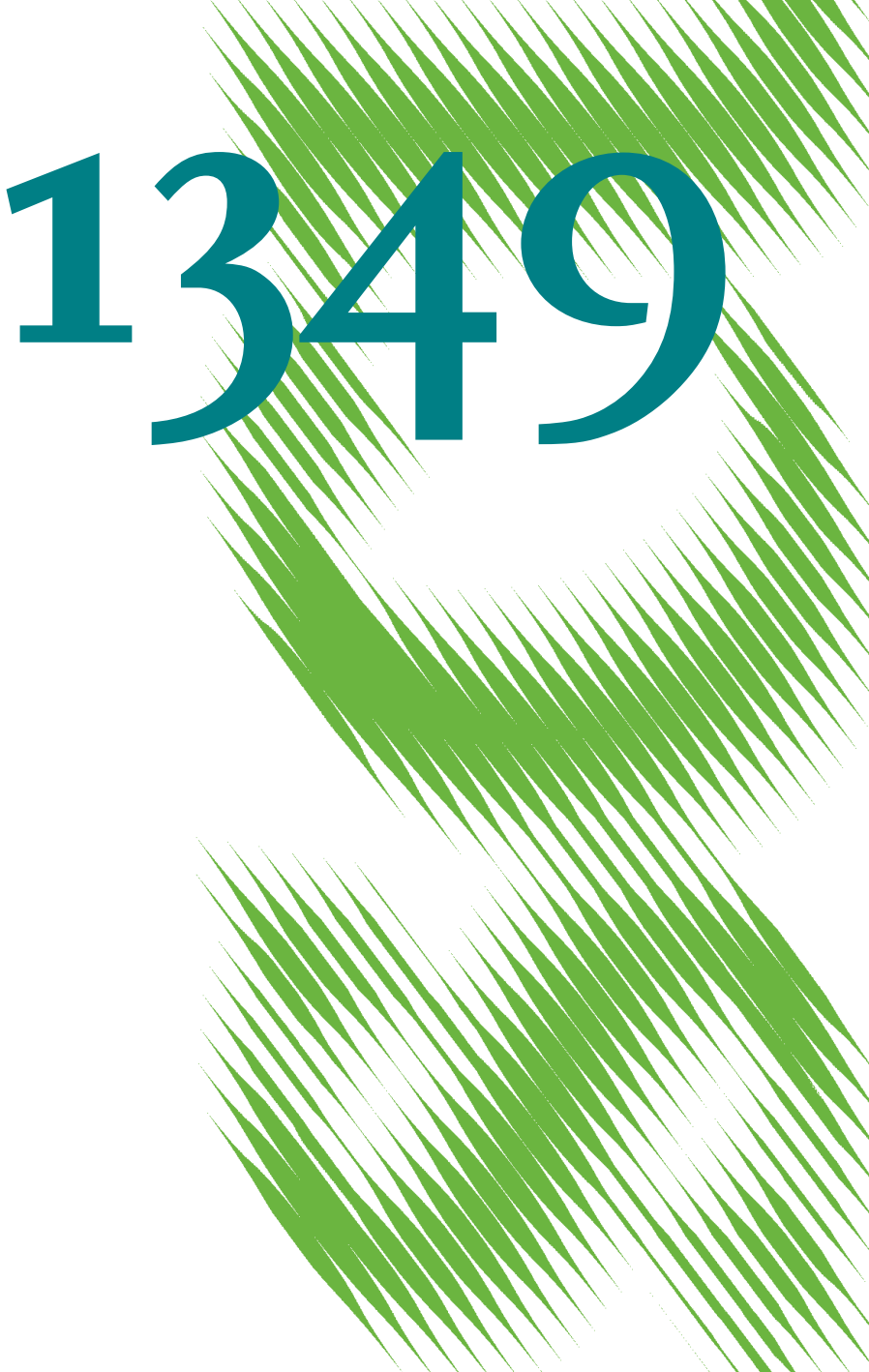

MM
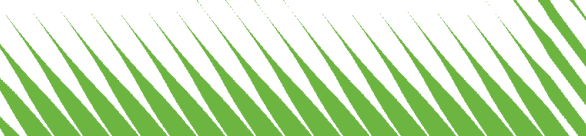

What Influences Banks' Choice of Risk Management Tools?

Theory and Evidence 
Opinions expressed in this paper are those of the author(s) and do not necessarily reflect views of the institute.

IMPRESSUM

(C) DIW Berlin, 2013

DIW Berlin

German Institute for Economic Research

Mohrenstr. 58

10117 Berlin

Tel. $+49(30) 89789-0$

Fax +49 (30) $89789-200$

http://www.diw.de

ISSN print edition $1433-0210$

ISSN electronic edition 1619-4535

Papers can be downloaded free of charge from the DIW Berlin website:

http://www.diw.de/discussionpapers

Discussion Papers of DIW Berlin are indexed in RePEc and SSRN:

http://ideas.repec.org/s/diw/diwwpp.html

http://www.ssrn.com/link/DIW-Berlin-German-Inst-Econ-Res.html 


\title{
What influences banks' choice of risk management tools? Theory and evidence
}

\author{
Dilek Bülbül ${ }^{\mathrm{a}, *}$, Hendrik Hakenes ${ }^{\mathrm{b}}$, Claudia Lambert ${ }^{\mathrm{c}}$ \\ ${ }^{a}$ Goethe-University Frankfurt, House of Finance, Grüneburgplatz 1, 60323 Frankfurt am Main, Germany \\ ${ }^{b}$ University of Bonn, Adenauerallee 24-42, 53113 Bonn, Germany, MPI Bonn and CEPR \\ ${ }^{c}$ DIW Berlin, German Institute for Economic Research, Mohrenstr. 58, 10117 Berlin, Germany
}

\begin{abstract}
This paper investigates the factors influencing banks' decision to engage in advanced risk management, from both a theoretical and an empirical perspective. In recent decades, credit risk management in banks has become highly sophisticated and banks have become more active and advanced in the management of credit risks. We identify two driving factors for risk management: bank competition and sector concentration in the loan market. We find empirical support for our hypotheses, using a unique data set of 249 German banks; parts of the data set are hand-collected. Bank competition pushes banks to implement advanced risk management. Sector concentration in the loan market promotes credit portfolio modeling, but inhibits credit risk transfer.
\end{abstract}

Keywords: banking, risk management, credit risk, credit portfolio modeling, credit risk transfer

\footnotetext{
${ }^{2}$ We thank the German Savings Banks Association (DSGV) for providing the data used in this study. We are grateful to the participants of the Southern Finance Associaton Conference in Asheville, the INFINITI Conference on International Finance in Dublin, the International Risk Management Conference in Florence, the International Tor Vergata Conference in Banking and Finance in Rome, the Conference of the Swiss Society for Financial Market Research (SGF) in Zürich, and the Financial Engineering and Banking Society Conference (FEBS) in London for useful comments and suggestions. We are in particular indebted to the prize committee of FEBS who awarded this paper the first prize (best FEBS 2012 paper), offered by the ESCP Business School. The paper represents the authors' personal opinions and not necessarily those of the German Savings Banks Association. All remaining errors are our own.

${ }^{*}$ Corresponding author: phone +49 69798 33663, fax:+49 6979833900

Email addresses: buelbuel@finance.uni-frankfurt.de (Dilek Bülbül), hakenes@uni-bonn.de (Hendrik Hakenes), clambert@diw.de (Claudia Lambert)
} 


\section{Introduction}

Credit risk management in banks has become highly sophisticated (Hellwig, 2010). ${ }^{1}$ This development was encouraged by regulators even before the financial crisis. However, recent market turmoil has exposed weaknesses in credit risk analysis. A report of the Senior Supervisors Group (2008), which identifies risk management practices during the recent market turbulence, shows that risk measures did not perform as expected. This has drawn further attention to banks' credit risk management, and shown how crucial the implementation and maintenance of risk management instruments is to the banking industry.

As financial institutions have grown more complex, the demand for risk management has grown rapidly (Bank for International Settlements, 2009). Hence, risk management has become one of banks' main activities (see e.g. Allen and Santomero, 1997; Santomero, 1997) and can be seen as banks' core competence (Hakenes, 2004).

Ambitious risk management tools have been developed over the last two decades for the modern practice of bank management. Altman and Saunders (1998) emphasize the development of credit-scoring systems, the development of models to measure and manage credit concentration in loan portfolios and the expansion of off-balance sheet instruments such as credit risk derivatives. Nevertheless, the financial industry has only gradually adopted such instruments, and their use is still not widespread among banks. Cebenoyan and Strahan (2004) emphasize that the use of risk management affects investment decisions, the value of a firm and its profitability. The cost of financial distress and the existence of capital market imperfections are also given as rationales for active risk management (see e. g. Stultz, 1984; Froot et al., 1993). However, because the implementation and upgrade of risk management involves a certain cost, it appears that there must be some trade-off between the costs and advantages of implementing sophisticated risk management instruments in order to be able to pursue advanced risk management.

Consequently, the question arises as to what determines whether the expected benefits of sophisticated risk management outweigh its costs. We aim to understand what factors influence banks' decisions to engage in advanced risk management from both a theoretical

\footnotetext{
${ }^{1}$ Credit risk management is defined as the set of measures to assess and manage credit risk. Risk management is seen as a core driver of bank performance, see Ebrahim et al. (2013).
} 
and an empirical perspective. We first develop a framework to analyze banks' decisions to engage in advanced risk management which we define as risk management where sophisticated risk management instruments are utilized in addition to traditional methods of risk management. In the model, a bank can implement credit portfolio modeling, engage in credit risk transfer, or be more advanced in managing credit risk by implementing both. Credit portfolio modeling allows the bank to understand its portfolio structure and, thus, to adjust its risk buffers. With credit risk transfer, the bank diversifies its portfolio by selling part of that portfolio.

We show that bank competition pushes banks to implement credit portfolio models and to engage in risk transfer markets. If competition is low, bank earnings are relatively high, which contributes to greater bank stability, therefore the benefits of buffer adjustments and diversification cannot be high for such banks. Sector concentration in the loan market promotes credit portfolio modeling but inhibits credit risk transfer. If sector concentration is low, the bank already knows that its portfolio will be diversified, credit portfolio modeling is, therefore, less beneficial. Moreover, with low sector concentration, the bank has more possibilites to diversify even within the region.

To empirically test these theoretical results, we use a probit regression model on crosssectional data. We conducted a survey in 2009 among 438 savings banks of the German Savings Banks Finance Group. In total, 279 completed questionnaires were returned; the response rate is, thus, greater than 60 percent. We combined this data with a unique data set of detailed balance-sheet, income-statement data and regional economic data. First, we can directly relate the use of different risk management instruments to bank characteristics, and to market and regional conditions. Furthermore, our sample allows for a bank-level analysis of bank competition and sector concentration because the business activities of the banks in our sample are limited to a specific geographical area, following the so-called "regional principle". Third, we are able to provide unbiased results because the banks in our sample face identical prices to implement credit risk management instruments and can access the same credit management instruments. They operate within the same regulatory environment and have a common business model but they are legally and economically independent in their business decisions. Finally, the German banking system is representative of other European economies such as Spain, France, and Switzerland. Our results can, thus, be generalized to other banking systems with a long history of savings banks.

We find that the determinants for banks' decision to engage in sophisticated or advance 
risk management are not only bank characteristics. We provide empirical evidence that sector concentration and competition among banks is positively related to a banks active risk management. We find evidence for the hypothesis that credit portfolio modeling should be prevalent when the sector concentration is relatively high. The depth of implementation and the integration of advanced credit risk management are primarily driven by competition among banks. The main results prove to be robust regarding different model specifications.

Our findings contribute to the broad body of literature on the impact of competition on banks' risk-taking behavior (see e.g. Keeley, 1990; Jiménez et al., 2010; Bergstresser, 2008) and are consistent with the "charter value" argument. However, we also make a complementary addition to the literature by explicitly incorporating risk management into the model and testing for it empirically. Furthermore, our findings coincide with those of Hakenes and Schnabel (2010) who investigate the role of banking competition for the credit derivative markets. They provide arguments why credit risk transfer markets developed in an environment of increasing competition. We can also empirically confirm the results of Khandwalla $(1972,1973)$ who investigates conditions under which sophisticated management controls are extensively used. He stresses that firms under competitive pressure use sophisticated controls more extensively and more selectively than firms facing less intense competition.

The empirical literature on advanced risk management mainly focuses on the investigation of individual risk management instruments. Cebenoyan and Strahan (2004) investigate empirically the impact of advanced risk management, proxied by loan sales and purchases. Numerous studies examine the factors underlying banks' decisions to use derivatives (see e. g. Sinkey and Carter, 2000; Ashraf et al., 2007; Minton et al., 2009). To our knowledge, there are no papers that investigate the underlying decisions to adopt credit portfolio models. A paper by Acharya et al. (2006) studies the effect of diversification on the riskreturn profile of banks. This study evaluates the decision of whether to focus or diversify loan portfolios, but it does not provide the factors for the underlying decision to engage in active portfolio management.

Whereas earlier research focused on individual risk management instruments, our study expands on prior work by modeling and empirically investigating banks' motivation to engage in advanced risk management through both credit portfolio modeling and participation in the credit risk transfer markets. This more integrated view of advanced risk management provides a sound understanding of the drivers of risk management in 
banking.

The remainder of the paper is structured as follows. Section 2 develops the model and derives the predictions, which are tested empirically. Section 3 describes the risk management of the banks and provides background information. Section 4 introduces the sample and variables used for the empirical analyses and presents tables of descriptive statistics. The empirical results are presented and discussed in section 5 . In section 6 we employ further robustness tests. Section 7 concludes the study. All tables appear in the appendix.

\section{A Model of Risk Management}

Theories on Risk Management. The literature on credit risk transfer is large and growing, especially due to the significance of credit risk transfer (CRT) during the recent financial crisis. Most papers, such as the seminal Pennacchi (1988) or C.A. Parlour (2008), focus on banks' monitoring activities. In Hakenes and Schnabel (2010), banks do not monitor loans, but face moral hazard because they can grant negative-NPV loans. Many recent papers consider the effect of risk transfer and diversification on financial (in)stability (see Allen and Carletti (2006), Wagner (2010), Purnanandam (2011), Ibragimov et al. (2012), just to name a few important contributions). Our paper focusses on the determinants of a single bank's decision, abstracting from any macro effects.

The second type of risk management in our model is credit portfolio modeling (CPM). It considers a banks' benefit of simply assessing the risk structure of its portfolio. Surprisingly, there is a wealth of research on the statistical and technical aspects of the quantification of bank risk. Also, there are many models in which banks gather information about single loans (just to name two examples, Broecker (1990) considers information gathering under competition, and Stein (2002) focuses on hard and soft information in hierarchies). We are not aware, however, of any model where banks gather information on its portfolio structure. In reality, risk management comprises both, information about single assets, and the correlation between assets.

\subsection{The Model}

Competition. We model a bank that holds a portfolio of two assets, each with a volume of 1. The expected return of an asset is $R>1$, such that $R$ can be interpreted as a measure 
of competition, which is treated as exogenous in the model. A high $R$ denotes for low competition, and vice versa. Assets are risky. For exposition, assume that the return is normally distributed with standard deviation $\sigma$. Henceforth, let us call the assets loans, bearing in mind that they could be any type of risky asset. ${ }^{2}$

The bank is financed with deposits $d$ and equity $k$. The balance sheet equation is $d+k=2$, thus $d=2-k$. Depositors demand a return of $r_{d}$ (equal to 1 plus the rate of return) which is taken as exogenously given. Deposits are covered by deposit insurance, and the deposit rate is normalized to zero, thus $r_{d}=1$. To obtain an interior solution for the capital structure and for simplicity, assume that the cost of equity is increasing in volume and the rate is $r_{k}=1+\phi k / 2$. If the bank cannot repay deposits from their loan portfolio, it defaults at a cost $c>0$. Note that $k$ can also be interpreted as a buffer or reserve against potential loan losses. ${ }^{3}$

Sector Concentration. Loans come from different industrial sectors, with masses $\mu_{1}, \mu_{2}$, $\ldots$, such that $\sum_{i} \mu_{i}=1$. The returns of loans from the same sector have a higher correlation than the returns of loans from different sector. For simplicity, set $\rho=1$ within a sector, and $\rho=0$ between sectors.

The Herfindahl-Hirschman-Index (HHI) is then $\sum_{i} \mu_{i}^{2}$. It is assumed to be public information, and has a second interpretation. If the bank picked two loans at random out of the pool, then the expected correlation would be $\sum_{i, j} \mu_{i} \mu_{j} \rho_{i, j}=\sum_{i} \mu_{i}^{2}=$ HHI. The sector concentration HHI is thus simultaneously a measure for the (lack of) diversification within a "natural" loan portfolio. Finally, assume that one of the sectors has discrete mass $\mu>0$, whereas the others have infinitesimal mass. The HHI then equals $\mu^{2}$. As we will see, this assumption simplifies the discussion of portfolios with many loans.

Risk Management Tools. The bank has access to two risk management tools. The first, credit portfolio modelling (CPM), is a passive tool. The bank learns the correlation structure of its loan portfolio, at a cost $c_{\mathrm{CPM}}$. Without CPM, the bank has expectations

\footnotetext{
${ }^{2}$ In reality, returns from loans cannot be normally distributed due to the unbounded support. The assumption of normality simplifies the model, it has no economic consequences.

${ }^{3}$ There are no capital requirements in the model, so that the capital structure is a choice variable. It is necessary for the model to have a choice variable that depends on the bank's risk. Loan loss provisions, and liquidity, would also work.
} 
about the likely correlation between its loans. With CPM, it learns whether the correlation is 0 or 1 . In the above context, the bank learns whether the loans are in the same sector or not. Banks can use the information generated by CPM to fine-tune their capital structure, depending on their portfolio. Without the information from CPM, the expected correlation of two loans is equal to HHI, and with CPM, it is either 1 (if both loans are in the same sector) or zero.

The second tool is called credit risk transfer (CRT). It costs $c_{\mathrm{CRT}}$ to implement. A bank originally has a balance sheet total of 2 , it can grant two loans. With CRT, it can sell a fraction of these loans, and use the receipts to grant new loans. One could think of the securitization of loans, or the use of credit derivatives in order to recycle regulatory capital. Let us assume, however, that this process cannot be driven ad infinitum. For concreteness, assume that the bank sells $50 \%$ of each loan, and grants two more loans, of which again it sells 50\%. The balance sheet total is then again 2. The same allocation would be obtained from initially granting two loans, then securitizing and selling $50 \%$ of each, and then using the receipts to buy securitized loans from another bank. CRT is thus a way to diversify. ${ }^{4}$

Finally, the bank can be maximally advanced in its management of credit risk by implementing both CPM and CRT. This is called advanced risk management (ARM), it comes at a cost of $c_{\mathrm{ARM}}$. Possibly, $c_{\mathrm{ARM}} \neq c_{\mathrm{CPM}}+c_{\mathrm{CRT}}$ due to (dis)economies of scope. This way, a bank can both diversify and fine-tune their buffers. Note that the value of CPM depends on whether the bank also uses CRT or not. Hence, ARM is more (or less) than the sum of its components, CPM and CRT. The relative value of each strategy, CRT, CPM or ARM, will depend on parameters, especially the level of competition and the sector concentration.

\subsection{The Optimal Strategy}

The optimal risk management strategy depends on the cost of implementation, and on the value of the according strategy. We start with calculating the expected profit if the benchmark case, where the bank uses neither credit portfolio modelling (CPM) nor credit

\footnotetext{
${ }^{4}$ In the model, there is only one bank, thus financial networks and contagion cannot be modeled. In reality, if banks insure credit risk using credit derivatives, its individual risk may decrease, but financial fragility may increase, see Krause and Giansante (2012) and other contributions in that special issue.
} 
risk transfer (CRT). We then calculate the bank's expected profit after the implementation of credit portfolio modelling (CPM). If the difference between the two exceeds the cost $c_{\mathrm{CPM}}$, the bank will prefer $\mathrm{CPM}$, and vice versa. We continue with the same calculation for credit risk transfer (CRT). ARM is the sum of CPM and CRT, hence we must compare it to the better of these two. We derive comparative static results for a situation when the bank prefers CPM, CRT or ARM.

The Benchmark Case. In the benchmark case, the bank uses none of the above risk management instruments. In reality, of course, banks are even required by law to have some basic risk management. We are interested in the endogenous method choice of banks, hence these basic instruments are outside the focus of our model. The bank has a balance sheet total of 2 , hence it grants two loans. These two are correlated with probability HHI $=\mu^{2}$, they are uncorrelated with probability $1-\mu^{2}$. The loan portfolio has the mean return $2 R$. If both loans are both in the discrete sector, they are correlated, and the standard deviation of the aggregate portfolio is $2 \sigma$. Hence the yield $Y$ is normally distributed with mean $2 R$ and standard deviation $2 \sigma$, thus $Y \sim \mathcal{N}(2 R, 2 \sigma)$. The bank has debt (deposits) of $d=2-k$. We want to determine the probability that the yield cannot cover deposit repayments, $Y<2-k$. The probability of such financial distress is given by the probability that the

$$
\mathrm{PD}_{1}=\operatorname{Pr}\{Y<2-k\}=\Phi\left(\frac{2-k-2 R}{2 \sigma}\right),
$$

where $\Phi(\cdot)$ is the standard normal distribution function. With probability $2 \mu(1-\mu)$, one of the loans is in the discrete sector, the other is in one of the infinitesimal sectors. With probability $(1-\mu)^{2}$, both loans are in one of the infinitesimal sectors. In both cases (aggregate probability $1-\mu^{2}$ ), the loans are uncorrelated. The standard deviation is then $\sqrt{2} \sigma$, thus $Y \sim \mathcal{N}(2 R, \sqrt{2} \sigma)$, and the probability of distress is

$$
\mathrm{PD}_{0}=\operatorname{Pr}\{Y<2-k\}=\Phi\left(\frac{2-k-2 R}{\sqrt{2} \sigma}\right)
$$

The aggregate expected profit of the bank equals the expected return, net of refinancing costs and the expected cost of financial distress,

$$
\begin{aligned}
\Pi & =2 R-d r_{d}-k(1+\phi k / 2)-\phi k^{2} / 2-c\left(\mu^{2} \mathrm{PD}_{1}+\left(1-\mu^{2}\right) \mathrm{PD}_{0}\right) \\
& =2 R-2-\phi k^{2} / 2-c\left(\mu^{2} \mathrm{PD}_{1}+\left(1-\mu^{2}\right) \mathrm{PD}_{0}\right) .
\end{aligned}
$$


The bank will choose the buffer $k$ to maximize the expected profits,

$$
\begin{aligned}
\frac{\partial \Pi}{\partial k} & =-\phi k^{*}+\frac{\mu^{2} X+\sqrt{2}\left(1-\mu^{2}\right) X^{2}}{2 \sqrt{2 \pi} \sigma} c=0, \quad \text { where } \\
X & =\exp \left(-\frac{\left(2-k^{*}-2 R\right)^{2}}{8 \sigma^{2}}\right)
\end{aligned}
$$

is an auxiliary variable. There is no algebraic solution to this implicit definition of $k^{*}$. However, the implicit function theorem can be used to compute some comparative statics. Most importantly for this paper, $\partial k^{*} / \partial R<0$. The more competition between banks, the smaller their interest margins, and the smaller the $R$, the more buffers banks need to hold against financial distress. Second, $\partial k^{*} / \partial \mu>0$. In the absence of credit portfolio management, banks do not know the exact correlation structure of their loan portfolio. However, if the sector concentration is high, the probability of a correlated portfolio is large, hence, the bank will hold higher buffers. The following Figure 1 shows the optimal $k^{*}$ depending on $R$ for the extreme cases of HHI $=\mu^{2}=1$ and HHI $=\mu^{2}=0$. In the numerical example, $c=10, \phi=2$, and $\sigma=0.2$. This numerical example will be used throughout this modelling section. For different parameter values, the picture is qualitatively identical.

Figure 1: Optimal capital buffer $k^{*}$ depending on competition (low $R$ ) and sector concentration

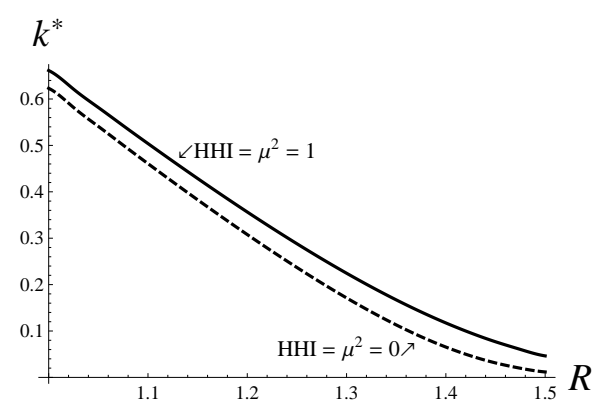

Two things can be seen from Figure 1. First, the bank will hold higher equity buffers for high competition (low $R$ ). For high competition, the bank's profits are small, so the bank prefers to insure itself against distress with a higher capital buffer $k^{*}$. Second, for a high sector concentration HHI, the bank prefers higher buffers $k^{*}$. The reason is that the bank does not know the precise correlation structure between loans, but it has expectations for a given sector concentration. The higher the concentration, the more likely are the loans to be correlated. More buffers are then needed. Both comparative statics are unsurprising. 
The more important question is, how can buffers be saved by the use of CPM, and under what conditions (competition, sector concentration).

Credit Portfolio Modelling (CPM). By implementing a credit portfolio model (CPM), the bank finds out the correlation within their loan portfolio. In other words, it determines whether each of the loans is in the discrete sector. Using this information, it can fine-tune the buffer. If it finds the correlation in its portfolio to be high, the aggregate standard deviation is high, and it needs larger buffers.

We now calculate the benefit of this piece of information. With probability $\mu^{2}$, the bank finds that both loans are in the discrete sector, hence, they are perfectly correlated. The probability of default is then $\mathrm{PD}_{1}$, as defined above in (1). The bank will then maximize the expected profit

$$
\Pi_{1}=2 R-2-\phi k^{2} / 2-c \mathrm{PD}_{1}
$$

which is maximized for $k_{1}^{*}$, as defined by

$$
\frac{\partial \Pi_{1}}{\partial k}=-\phi k_{1}^{*}+\frac{c}{2 \sqrt{2 \pi} \sigma} X=0
$$

where $X$ is the auxiliary variable defined in (4). If, with probability $1-\mu^{2}$, the bank finds that the loans are uncorrelated, the probability of default is $\mathrm{PD}_{0}$, as defined in (2). The expected profit is $\Pi_{0}=2 R-2-\phi k^{2} / 2-c \mathrm{PD}_{0}$, and the bank can reduce the buffer to $k_{0}^{*}$, according to the first order condition

$$
\frac{\partial \Pi_{0}}{\partial k}=-\phi k_{0}^{*}+\frac{c}{2 \sqrt{2 \pi} \sigma} \sqrt{2} X^{2}=0
$$

Ex ante, the expected profit is then the average of $\Pi_{1}$ and $\Pi_{0}$,

$$
\Pi_{\mathrm{CPM}}=\mu^{2} \Pi_{1}+\left(1-\mu^{2}\right) \Pi_{0}
$$

Thus, the benefit of credit portfolio modeling equals the difference between the expected profits with and without the information about correlations. Some facts are intuitive. For example, if $\mu=0$, then all the loans in a loan portfolio must be uncorrelated. Consequently, the correlation structure is already known, and the value added by further information is zero. For $\mu=1$, all the loans in a portfolio are perfectly correlated, and 
nothing more can be learned. Again, the value of additional information is zero. Third, the value of the information can never be negative.

Figure 2 shows the difference between the expected profits with and without CPM, for different degrees of competition and sector concentration. On each curve, the benefit of implementing CPM is constant. The difference in profits is plotted on the contours (in percentage points of the balance sheet total). Light shading means that the benefit of CPM is small, dark gray implies that the benefit is large. For example, take $R=1.0$ and $\mu=0.4$. The corresponding point in the figure is exactly on the 0.8 -curve. This implies that the benefit of having CPM implemented is $0.8 \%$ of the balance sheet total. If the cost of $\mathrm{CPM}$ were $c_{\mathrm{CPM}}=0.8$, the bank would be indifferent with respect to its implementation. For $c_{\mathrm{CPM}}<0.8 \% \cdot 2=0.016$, it would go ahead and implement CPM. One can thus read the figure as follows. For a given $c_{\mathrm{CPM}}$, find the according curve. The bank will implement CPM for all parameter constellations northeast of this curve.

Figure 2: Difference in profits, credit portfolio modelling (CPM) vs. benchmark

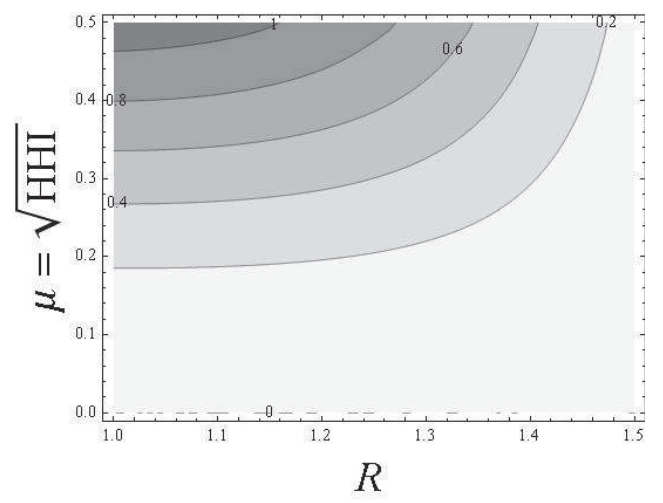

There are two apparent properties. First, CPM is especially valuable if competition is large, hence, $R$ is small. If $R$ is large, the probability of distress is small even in the absence of buffers. Regardless of whether the portfolio is correlated, the bank will hold only small buffers. Therefore, the impact of CPM information on the bank's behavior will be marginal. As a consequence, the information is not valuable. In contrast, if competition is high, the bank will likely suffer financial distress, and it will hold large buffers to insure against distress. By learning that its portfolio is relatively balanced, the bank can save a major fraction of these buffers. Hence, the CPM information is valuable if competition is high. 
Second, CPM is especially valuable if the sector concentration is large. The reason, as mentioned above, is that for $\mu=0$, the correlation structure can be guessed even in the absence of CPM. (The same would true for $\mu=1$, but given that $\mu^{2}$ equals the sector Herfindahl-Hirschman index, $\mu$ will realistically be closer to 0 than to 1 . Therefore, we have plotted Figure 2 only for $0 \leq \mu \leq 1$.) Hence, the larger the sector concentration, the more can be learned about the portfolio structure, and the more valuable CPM becomes. We arrive at the following proposition, delivering two hypotheses that will be tested in the empirical section of the paper. The proof is in Appendix D.

Proposition 1 (Credit Portfolio Modeling). For higher competition (lower $R$ ), CPM becomes more desirable. For larger sector concentration (higher $\mu$, up to some level), CPM becomes more desirable.

As a direct consequence, ceteris paribus, a bank in a region with high sector concentration will tend to implement CPM. A bank under tense competition will also tend to implement CPM. Let us now discuss the implications for the second risk management tool, credit risk transfer (CRT).

Credit Risk Transfer (CRT). Assume now that the bank can implement a credit risk transfer (CRT) technology. By doing so, it can securitize some part of each loan. Doing so, it can increase the number of loans it can grant. As argued above, we assume that this process cannot be driven ad infinitum (otherwise banks would end up with perfectly diversified portfolios). Only $50 \%$ of each loan can be securitized, the bank keeps the other $50 \%$ in its books. This implies that, with a balance sheet total of 2 , the bank can grant 4 half loans. With the correlation structure as before, there are five different possible constellations: (i) all the loans can come from the discrete sector (probability $\mu^{4}$ ); (ii) all but one loan can come from the discrete sector (probability $4 \mu^{3}(1-\mu)$ ); (iii) all but two loans can come from the discrete sector (probability $\left.6 \mu^{2}(1-\mu)^{2}\right)$; (iv) only one loan can come from the discrete sector (probability $\left.4 \mu(1-\mu)^{3}\right)$; and (v) all loans can stem from the infinitesimal sectors (probability $\left.(1-\mu)^{4}\right)$. Depending on the correlation structure, the probability of default will differ. However, the benefit of CRT consists only in the increased diversification within the portfolio. In the absence of further information (that could stem from CPM), the bank cannot adjust buffers to the different constellations.

In the first scenario (case (i), probability $\mu^{4}$ ), the standard deviation of the portfolio is $2 \sigma$, hence, the probability of default is $\operatorname{Pr}\{Y<2-k\}=\Phi\left(\frac{2-k-2 R}{2 \sigma}\right)$. In the second scenario 
(case (ii), probability $4 \mu^{3}(1-\mu)$ ), three loans are correlated, the fourth is independent. The standard deviation is $\sqrt{(3 \sigma / 2)^{2}+(\sigma / 2)^{2}}=\sqrt{5 / 2} \sigma$, and accordingly, the probability of default is $\Phi\left(\frac{2-k-2 R}{\sqrt{5 / 2} \sigma}\right)$. In the third scenario (case (iii), probability $6 \mu^{2}(1-\mu)^{2}$ ), two loans are correlated, and all others are mutually independent. The standard deviation is $\sqrt{(2 \sigma / 2)^{2}+(\sigma / 2)^{2}+(\sigma / 2)^{2}}=\sqrt{3 / 2} \sigma$, and the probability of default is $\Phi\left(\frac{2-k-2 R}{\sqrt{3 / 2} \sigma}\right)$. Finally, in the latter two cases (iv) and (v), all the loans are stochastically independent, so with probability $4 \mu(1-\mu)^{3}+(1-\mu)^{4}$, the portfolio has maximal diversification. The standard deviation is $\sqrt{(\sigma / 2)^{2}+(\sigma / 2)^{2}+(\sigma / 2)^{2}+(\sigma / 2)^{2}}=\sigma$, and the according probability of default is $\Phi\left(\frac{2-k-2 R}{\sigma}\right)$.

Taking these default probabilities into account, the bank will set the optimal buffer $k^{*}$. Inserting this into the profit function and comparing it with the expected profits in the benchmark case, we can plot the following Figure 3. Again, dark gray denotes for large benefits of CRT, and white denotes for small benefits. Note that a more diversified portfolio always has a smaller probability of default. Therefore, the bank can economize on buffers. Hence, the profits with CRT always exceed those in the benchmark case.

Figure 3: Difference in profits, credit risk transfer (CRT) vs. benchmark

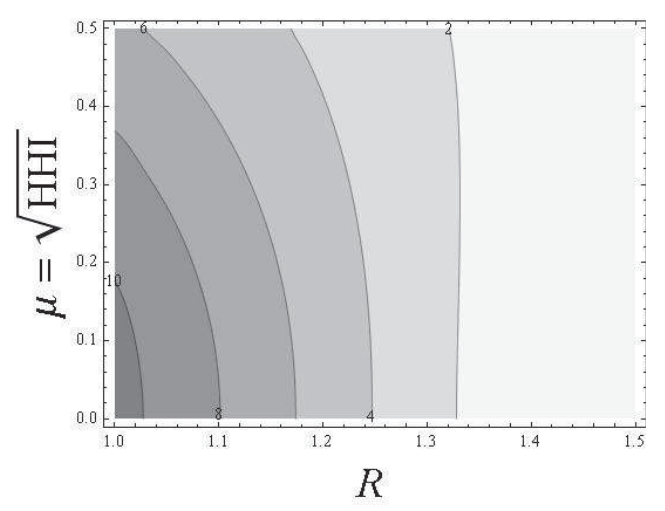

We observe a number of further properties. First, the higher the competition (lower $R$ ), the more beneficial credit risk transfer becomes. The intuition is similar to that for CPM. If $R$ is rather large, then the probability of default is small even in the absence of CRT. CRT then lowers the probability of default even further. However, given that the PD is already at a low level, the benefit cannot be large. Hence, if competition is low, there is not much scope for large benefits from CRT. In the figure, the shading is white for large $R$. For smaller $R$, the argument goes in the opposite direction, hence, the benefits from CRT can be large, and the shading in the numerical example is darker. 
Second, the benefit of CRT is highest if sector concentration is low. To understand why, take the extreme of $\mu=1$. Then, both loans are perfectly correlated with probability 1. If these loans are securitized, the two new loans will also be perfectly correlated. The correlation structure is unchanged by CRT. Thus for $\mu=1$, the benefit of CRT is exactly zero. The lower the sector concentration, the larger the benefit of CRT is because the probability of arriving at a balanced portfolio becomes larger. Therefore, we have darker shading especially for low degrees of $\mu$. Again, we arrive at a proposition containing two hypotheses, which will be tested in the empirical section of the paper.

Proposition 2 (Credit Risk Transfer). For higher competition (lower R), CRT becomes more desirable. For larger sector concentration (higher $\mu$ ), CRT becomes less desirable.

Considering a cost $c_{\mathrm{CRT}}$ for implementing CRT, the bank will opt for CRT if the benefit exceeds the cost. For example, if the cost were $c_{\mathrm{CRT}}=0.12$, this is $6 \%$ of the balance sheet total of 2 . The bank will implement CRT for all parameter constellations southeast of the 6 -line.

Advanced Risk Management (ARM). We have considered the benefits to banks of gathering information about their portfolio structure (CPM), and diversifying to reduce the granularity of their loan portfolio (CRT). Now let us define advanced risk management $(\mathrm{ARM})$ as the choice to implement both. In our model, this is the most sophisticated level of risk management: risk is measured and diversified, and the buffers are adjusted. Using ARM, a bank can learn exactly how its portfolio is structured within its portfolio, ending up in five cases, as discussed above: (i) all four loans can be correlated; (ii) all but one can be correlated; (iii) all but two can be correlated; or (iv and v) all may be uncorrelated. In each case, the bank will then set a different buffer. In the first case, the buffer will be relatively high, and in the last case, it will be relatively low. Calculating the profits in all four scenarios, weighting them with the according probabilities, and calculating the aggregate expected profits, we can calculate the benefits of ARM in comparison to the second-best alternative. Because CRT and CPM always dominate the benchmark case, only CRT or CPM can be the best alternative. The numerical simulation results in the following Figure 4.

Figure 4 demonstrates a couple of regularities. First, and under the same reasoning used previously, a higher level of competition (low $R$ ) implies larger benefits of advanced risk 
Figure 4: Difference in profits, advanced risk management (ARM) vs. best alternative

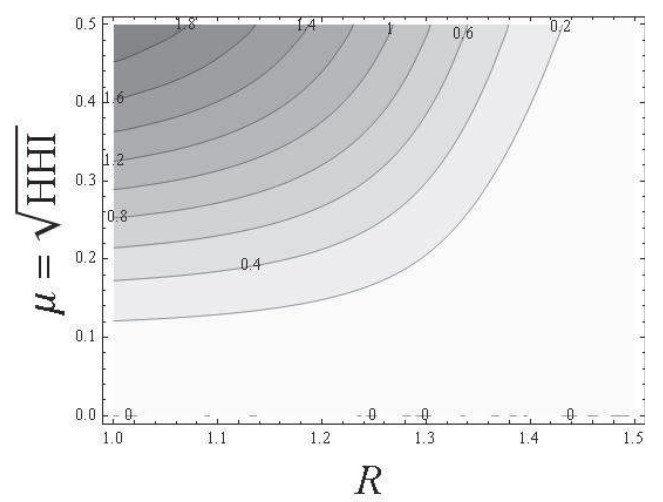

management (ARM). If $R$ is large, the probability of distress is small in the first place, so risk management cannot have large benefits. Second, the value added of ARM is larger for larger sector concentration. If the sector concentration is low, then the correlation structure is obvious to the banker, and all the loans must be uncorrelated. Consequently, ARM must be equally as beneficial as CRT. The same argument applies for $\mu=1$, but because $\mu^{2}$ gives the sector Herfindahl-Hirschmann index, $\mu=1$ would imply that there is only one sector in the region, which is unrealistic. This is the reason why we concentrate on smaller values for $\mu$. We arrive at two hypotheses, to be tested in the empirical section of the paper, and proven in the appendix. Whether the bank implements ARM depends on the cost $c_{\mathrm{ARM}}$.

Proposition 3 (Advanced Risk Management). For higher competition (lower $R$ ), ARM becomes more desirable. For larger sector concentration (higher $\mu$ ), ARM becomes less desirable.

\section{Institutional Background}

This section provides background information on the credit risk management of the banks in our sample. The banks in the sample are public banks belonging to the German Savings Banks Finance Group (Sparkassen-Finanzgruppe). This banking group constitutes one pillar of the German "three-pillar" banking system. The other two pillars are private banks and cooperative banks. The public banks are legally and economically independent institutions. In their municipalities they provide financial services to retail customers 
and small and medium-sized enterprises. Lending of primarily illiquid and opaque loans (Morgan, 2002; Flannery et al., 2004) is conducted within a defined region the bank operates in - referred to as the "regional principle". In accordance with this principle banks are not allowed to expand their business to other regions.

The German Savings Banks Association (DSGV) is the umbrella organization of the German Savings Banks Finance Group and represents the interests of the group. It is responsible for realizing economies of scale in the infrastructure, developing standardized financial products and providing business services to all banks within the group. ${ }^{5}$ The DSGV developed a standardized approach to determining credit risk by creating a joint internal rating system, introduced in 2002. All the banks in our sample have implemented the same approved internal rating system. Therefore, all the banks follow similar processes to generate the rating classes. The rating classes are assigned to individual borrowers to indicate their degrees of creditworthiness. There are 18 rating classes, which can be translated to Moody's and Standard \& Poor's rating classes. The ratings are used for internal risk management and regulatory capital calculations. The available ratings allow banks to calculate the credit risk on the individual and portfolio levels. In our sample almost all the banks calculate their credit risk using the Standardized Approach. ${ }^{6}$

In principle, the banks may use any credit portfolio model for assessing and managing their risk exposure at the portfolio level. Crouhy et al. (2000) compares various credit portfolio models, such as CreditMetrics, KMV, CreditRisk+ and CreditPortfolioView and concludes that any of these can be considered reasonable internal models. Therefore, credit portfolio models represent a way to actively manage risk at the portfolio level.

The majority of the banks in our sample use CreditPorfolioView ${ }^{7}$, which was adapted to the specific needs of the banks in the German Savings Banks Finance Group. This project was conducted by the umbrella organization of the banking group in cooperation

\footnotetext{
${ }^{5}$ For detailed descriptions and analyses of the German banking sector, see Krahnen and Schmidt (2004). A detailed discussion of the German Savings Banks Finance Group is provided by Schmidt (2009). Further information can be obtained from the German Savings Banks Association (DSGV, 2011).

${ }^{6}$ Only one bank uses the IRB (Internal Ratings Based) Approach. Under the Standardized Approach, risk weights range from $0 \%$ to $150 \%$ depending on the category of the claim (e.g. sovereigns, corporates, retail products etc.) and the respective rating.

${ }^{7}$ CreditPorfolioView is an instrument that measures the credit risk of a bank in its portfolio - both from a periodical and value-oriented perspective.
} 
with McKinsey \& Company. Moody's (2010) confirms that back-office credit activities benefit from such standardized approaches through uniform instruments, available to all banks. Therefore, basically all the banks have access to the same product at comparable costs. For a bank to use the credit portfolio model, the bank must pay a fee following a two-stage cost structure. First, the bank is required to pay a one-time fee when obtaining the model and, second a monthly fee on a regular basis. The one-time implementation fee is negligibly low and the monthly fee is proportional to the size of the bank. Consequently, small banks pay less than larger banks. Therefore, the adoption of credit portfolio models is also affordable for smaller banks.

CreditPortfolioView considers changes in market values and credit ratings, and considers the relationship between default probabilities and underlying macroeconomic factors (i. e., default frequencies increase during a recession). The model links default statistics with factor models to industry- and country-specific variables and is used for the determination of key risk figures. One commonly used risk measure to assess a bank's loan portfolio risk is Value-at-Risk (VaR). Using the credit portfolio model, the bank can additionally evaluate the impact of new loans on the overall portfolio risk. As such, the bank can analyze the impact of rating changes and macro or micro changes. Furthermore, the credit portfolio model allows a bank to undertake stress testing on a daily basis or less frequently, at least once a month, depending on the type of credit exposures in its portfolio, ranging from simple unsecured to more complex products such as structured exposures or securitization (as the market value of capital market products is subject to frequent chances) to derive appropriate strategies.

Additionally, banks become involved in advanced credit risk management by participating in credit risk transfer markets. The banks in our sample either participate in internal risk transfer markets through credit pooling (Kreditpooling) or make use of market-based solutions, such as Credit Default Swaps (CDSs) or Collateralized Debt Obligations (CDOs). The banks can participate in the external risk transfer market and in the internal loan pool, both as issuers of risk (protection buyer) and as buyers of risk (protection seller). The inter-regional credit pooling transactions are affected via Credit Linked Notes (CLNs). Since 2002, one credit basket has been issued within the banking group approximately every year. According to Gintschel and Hackethal (2004) banks participating in credit pooling transactions can significantly reduce the risk of loans by diversifying their loan portfolio. The underlying credit risk of the loan remains in the bank's portfolio, hence, the relationships with the participating banks and their customers remain unaffected. From the annual statements of the banks in our sample, it is apparent that credit derivatives 
are used for both purposes.

Given the theoretical advantages of advanced risk management through credit portfolio models and credit risk transfer instruments, banks should be inclined to operate these instruments. However, from our sample, we observe that only a limited number of banks adopt these advanced risk management tools. This phenomenon is not unique to our sample. For example, in the U.S. although the volumes in the derivatives markets are high, only a limited number of banks participate in risk transfer markets. According to the Office of the Comptroller of the Currency (2009), five large commercial banks represent 97 percent of the total U.S. banking industry notional amounts. Moreover, the Joint Forum (2008) of the Bank for International Settlements prepared a report based on a 2008 survey to explore the progress that financial conglomerates have made in identifying, measuring, and managing risk concentration. It is reported that most of the surveyed firms stated that they manage credit risk concentration through traditional methods, such as the use of internal risk limits on exposures to particular obligor names, industry sectors, geographic regions, and product types. In this sense, banks have always been engaged in loan portfolio management. However, traditional methods do not explicitly consider the correlation of loan positions as is the case of credit portfolio modeling. The interdependency of credit risk is measured by correlation. Credit portfolio modeling accounts for that, otherwise the risk of the portfolio could be mismeasured. Similarly, Düllmann and Masschelein (2007) find that, for a concentrated portfolio, the required economic capital increases.

\section{Identification strategy, data and summary statistics}

This section describes the data and variables we use to test the hypotheses described in the preceding sections. We provide descriptive statistics for the variables used in the empirical analyses.

\subsection{Data}

For our research, we merged three data sets: Banks' balance-sheet and income-statement data, regional economic data, and survey data. The balance-sheet, income-statement and survey data are provided by the German Savings Banks Association (DSGV), whose databases is used in various studies (Puri et al., 2011); the survey data in particular in Bülbül (2013). 
For our analysis we use a data sample of regional banks operating within defined regions in Germany following the "regional principle". We have access to a unique panel data set provided by the DSGV. Our data includes balance-sheet and income-statement data observed annually and covers the period from 2002 to 2006. In 2008, a total of 438 regional banks existed in Germany, operating in rural and metropolitan areas.

For our analyses, we also use regional economic data provided by the Statistical State Offices available for the 439 administrative districts in Germany. ${ }^{8}$ Additionally, we conducted a paper questionnaire survey to elicit the necessary information on credit risk management. The survey was conducted in April 2009 and was primarily answered by top management. Of 438 questionnaires sent to all savings banks from the German Savings Banks Finance Group, a total of 279 completed questionnaires were returned. This equals a response rate of more than 60 percent. For our analyses we used 249 responses because some banks returned the questionnaire without the front page containing the name of the bank. Banks that had been involved in a merger since 2006 are excluded from the sample because historical data is not available for these new entities.

We observe that the participating banks are slightly larger than non-participating banks. Total assets of particpating average around 2.45 billion Euros while for non-particpating banks the average amounts to approx. 1.91 billion Euros, the difference being statistically significant but economically negligible. Thus, comprising 57 percent of the banks participating in the survey, our sample is highly representative of all regions and asset classes.

In the survey the banks were asked to provide information on the instruments used in their daily corporate businesses to manage credit risk. The respondents were asked to qualify the intensity of their use of different risk management tools as frequent, occasional or no use $\mathrm{u}^{9}$.

For our analyses we also use balance sheet and income statement data for the 2002 to 2006 period for three reasons. First, we are restricted to data before 2006, simply because we use unique and as such very detailed balance sheet data, which was provided to us from

\footnotetext{
${ }^{8}$ These administrative districts are classified as level 3, according to the Nomenclature of Territorial Units for Statistics (NUTS). This definition allows us to investigate region-specific variables such as the regional GDP, number of inhabitants, and sector concentration.

${ }^{9} \mathrm{~A}$ detailed description of the questionnaire is available in Appendix A.
} 
the DSGV only for the period before 2006. Second, we constrain our sample to the period following 2002 because the banks in our sample adopted a group-wide strategy including large reorganizational activities. These structural changes included the introduction of standardized approaches to risk management and other business areas ${ }^{10}$. Third, since we combine the balance sheet data, conducted in 2009, with information on the use of risk management instruments from the survey, we have to make sure that responses given in the questionnaire apply also to the years before. In general, the implementation and operation of risk management instruments is a long-term endeavor. Risk management instruments such as CreditPortfolioView, credit pooling and the internal rating system were first introduced in 2002, partly as a consequence of the structural changes triggering a new group wide strategy. We have spoken to the banks that participated in the survey and learned that the decision to use these risk management tools is likely to be constant over the years after the implementation in 2002. This allows us to merge the survey answers directly to the balance sheet data.

\subsection{Variables}

In this section we provide a detailed overview of the variables we use in our analysis. First, we explain how risk management strategies of banks can be derived from the survey and, second, we define factors that potentially influence a bank's decision to implement advanced risk management tools.

\subsubsection{Risk management strategies in banks}

Based on the survey data, we construct three dependent variables: ARM, CRT and CPM. A more detailed description of the exact construction of these variables follows below. In general, the variables are constructed from the following survey questions, ARM being a combination of CRT and CPM:

- CRT: Which of the following instruments for credit risk management are used in your savings bank?

\footnotetext{
${ }^{10}$ Structural changes also included the abolishment of state guarantees pioneered by the acceptance of the amendment of state guarantees for German public banks of the European Commission's proposal on April 11, 2002 (see Moser and Soukup, 2002). However, the discussion of the removal of the State guarantees began much earlier. To guarantee competitiveness, the restructuring of the public banks was inevitable after the abolishment of the state guarantees.
} 
- Credit risk transfer (credit pooling)

- Credit risk transfer (credit derivatives)

- CPM: How intensively does your bank use the results from quantitative credit portfolio analyses (CPV, other) for active management of the credit portfolio?

Credit risk transfer ( $\boldsymbol{C R T}$ ). In the questionaire the banks were able to classify the intensity of the use of risk management instruments as no use, occasional use or frequent use. ${ }^{11}$ We define the binary variable CRT to be one when either internal markets for credit derivatives (credit pooling) or the market-based solution for credit derivatives is used frequently or occasionally, and zero otherwise. As such, we impose that either frequent or occassional use of these instruments is sufficient for a bank to be classified as being active in credit risk transfer markets. Intuitively, this makes sense, as the frequency of participation in the credit risk transfer market depends on the specific business of the bank. Consequently, either form of participation is recognized. We construct this variable from question 12-10 and 12-11 of the survey in the appendix.

Credit portfolio modeling ( $\boldsymbol{C R} \boldsymbol{M})$. The binary variable CPM is one when the credit portfolio model is employed frequently to measure and manage credit risk, and zero otherwise. In the questionaire the banks were able to classify the intensity of the use of risk management instruments as no use, occasional use or frequent use. Employing a credit portfolio model for monitoring and actively managing the portfolio occasionally means using the instrument at most once a month, whereas frequent use implies using the instrument much more often. Given that frequent use allows the bank to actively monitor and manage their credit portfolio, we, therefore, only include these banks. Reasonable lending strategies of banks can be derived if banks actively monitor their portfolio and also use the results for their business decisions. We construct this variable from question 13-3 of the survey in the appendix.

Advanced risk management (ARM). Finally, ARM is a binary variable being one if CRT and CPM are used simultaneously, and zero otherwise. Here, the bank engages in the highest level of advanced risk mangeement as definied in our theoretical model.

\footnotetext{
${ }^{11}$ In the survey we did not require the participants to quantify there intensity of use by the number of application per month. As the quantity is very much dependent on the specific business of the bank, banks' qualitative judgement (own judgement) on this issue is much more appropriate to investigate our research question.
} 


\subsubsection{Potential determinants of risk management strategies}

In this section we provide an overview of potential determinants influencing banks' decision for risk management. The following variables are obtained from banks' balance sheets, banks' income statement data and regional economic data.

Risk-Return Profile. We measure the risk-return profile of a bank using three separate variables: net-interest income to total income (see e.g. Ashraf et al., 2007), netcommission income (non-interest) to total income (see e.g. Beltratti and Stulz, 2012; Brunnermeier et al., 2011) and the ratio of loan loss provisions to total assets (see e.g. Minton et al., 2009). We consider net-interest income because the income is directly related to the bank's lending business. Banks participate in risk transfer markets either to hedge and as such reduce their risk exposure or to generate fee income by selling risk management services. Banks that are keen on generating profits are likely to use credit derivatives for profit creation rather than pure risk hedging. Furthermore, banks can manage the risk-return profiles of their portfolios through active portfolio management. Banks may engage in advanced risk management to generate additional profits and/or reduce risk exposure. Therefore, we expect banks with less interest income and higher loan loss provisions to be more likely to involve in advanced credit risk management.

Capital adequacy. We include the equity to total asset ratio (see e.g. Minton et al., 2009) because banks' have to fullfill minimum capital requirements in accordance with the risk they carry. As a consequence this may influence a bank's decision to implement advanced risk management tools. On the one hand banks want to ensure against future losses, on the other hand, banks do not want to hold capital in excess of what is required. Therefore, in particular the adoption of credit portfolio models is likely to allow better monitoring and a more adequate determination of economic capital. Monitoring through credit portfolio models first and transferring credit risk transfer markets second enhances the quality of risk management because banks have better measures at hand to fine-tune the compositions of their loan portfolios. In general the motivation to engage in advanced risk management should be influenced by the level of equity available to each bank.

Portfolio concentration. Given that the banks in our sample conduct business in a defined regional area according to the "regional principle", the sector concentration in the 
respective region proxies the lending portfolio of each bank. The Herfindahl-HirschmanIndex is used to estimate the sector concentration in region $i$ (for bank $i$ ) and is calculated as

$$
\operatorname{HHI}(\mathrm{x})_{i}=\sum_{n=j}^{N} \mathrm{x}_{j}^{2}
$$

where $\mathrm{x}_{j}$ is the share of the number of firms conducting business by the sectors $j$ over all the firms in the region $i$ as of $2005 .^{12}$

A bank with a concentrated loan portfolio will typically be more risky. Thus, it is not surprising that credit risk concentration has played a critical role in past bank failures in mature economies. The Basel Committee on Banking Supervision (2004) studied the patterns of bank failures in highly developed economies with long-functioning banking systems that were exposed to significant bank failures or banking crises during the past 30 years. They found that credit concentration risk was cited in nine of 13 bank failures. Involvement in advanced risk management may thus prevent risk concentration in the loan business. ${ }^{13}$ Düllmann and Masschelein (2007) show that it is necessary to take inter-sector dependency into account when measuring credit risk, for which credit portfolio models are a typical instrument. According to Batten and Hogan (2002) credit derivatives have a much more flexible approach to managing the risks associated with concentration. Both advanced instruments can be used to manage credit risk in the way that a lending portfolio is diversified by reducing its credit risk concentration. We expect banks with credit risk concentration proxied by sector concentration to be more likely to be involved in advanced risk management.

\footnotetext{
${ }^{12}$ According to the Statistical Classification of Economic Activities in the European Community twelve sectors are specified: (i) Mining and Quarrying; (ii) Manufacturing; (iii) Electricity, Gas, Steam and Air Conditioning Supply; (iv) Construction; (v) Wholesale and Retail Trade, Repair of Motor Vehicles and Motorcycles Transportation and Storage; (vi) Accommodation and Food Service Activities; (vii) Transportation and Storage; (viii) Financial and Insurance Activities; (ix) Real Estate Activities; (x) Education; (xi) Human Health and Social Work Activities and (xii) Other Service Activities.

${ }^{13}$ The Deutsche Bundesbank (2006) defines credit risk concentration as "concentration of loans to individual borrowers [...] and an uneven distribution across sectors of industry or geographical regions (sectoral concentration). A further risk category consists of risks arising from a concentration of exposures to enterprises connected with one another through bilateral business relations."
} 
Competition. A broad range of literature exists on the relationship between competition and the risk-taking behavior of banks. One body of literature argues that higher competition can lead to higher risk-taking in a bank (see e. g. Keeley, 1990; Hellmann et al., 2000; Jiménez et al., 2010; Bergstresser, 2008). According to recent studies, higher competition can also lead to less risk-taking by a bank (see e.g. Boyd and De Nicolo, 2005; Boyd and Jalal, 2006). Because risk-taking behavior and the use of risk management instruments should be related, we expect competition to have a significant effect on banks' decisions to be involved in advanced risk management. Given the relationship between competition and the risk-taking behavior of banks, we expect banks exposed to higher competition to be more likely to be involved in advanced credit risk management through the use of credit portfolio models and by participating in credit risk transfer markets. We use the Lerner index as a proxy for market power. We construct the Lerner index following Berger et al. (2009). The Lerner index (LERNER) measures how far banks can set prices above their marginal costs and is calculated as

$$
\mathrm{LERNER}_{i t}=\frac{\left(P_{i t}-\mathrm{MC}_{i t}\right)}{P_{i t}}
$$

where $P_{i t}$ is the price proxied by the ratio of total revenues (interest and non-interest income) to total assets and $M C_{i t}$ is the marginal cost, which is derived from the following translog cost function

$$
\begin{aligned}
\ln \operatorname{Cost}_{i t} & =\beta_{0}+\beta_{1} \ln \mathrm{TA}_{i t}+\frac{\beta_{2}}{2} \ln \mathrm{TA}_{i t}{ }^{2}+\sum_{k=1}^{3} \gamma_{k t} \ln W_{k, i t}+\sum_{k=1}^{3} \phi_{k} \ln \mathrm{TA}_{i t} \ln W_{k, i t} \\
& +\sum_{k=1}^{3} \sum_{j=1}^{3} \ln W_{k, i t} \ln W_{j, i t}+\epsilon_{i t}
\end{aligned}
$$

where banking output is proxied by the total assets $\mathrm{TA}_{i t}$ (see e. g. Carbo et al., 2009), and three input prices $W_{k, i t}$ are defined as the ratio of personnel expenses to total assets (price of labor), the ratio of interest expenses to total deposits (price of funding) and the ratio of operating and administrative expenses to total assets (price of capital). We estimate the equation by including yearly time-fixed and bank-fixed effects with robust standard errors using panel data covering the period from 1996 to 2006. We average the Lerner index for the observation period because we are interested in the competitive stance of the bank. 
Bank size. We proxy bank size by total assets. The larger the banks, the fewer the number of relationships that these banks have with their clients (Memmel et al., 2007). Consequently, the lending business is likely to be more opaque for these banks (Memmel et al., 2007) and thus, the likelhood is high for these institutions to become more involved in advanced risk management. Better monitoring through credit risk instruments may be more relevant for these banks. Additionally, larger banks typical have the resources (e.g. human capital) to adequately run these models and, the required knowledge to engage in advanced risk management (see e. g. Booth et al., 1984; Kim and Koppenhaver, 1993). Accordingly, we expect the size of the bank to have a significant effect on banks' decisions to engage in advanced risk management. To allow for nonlinearities between size and the use of risk management instruments we define four asset classes following Cebenoyan and Strahan (2004) and Demsetz (2000). The smallest quartile acts as the omitted category.

Lending and funding structure. We also account for the lending structure and funding structure of the bank. A bank's decision to engage in advanced risk management is potentially related to the composition of the loan portfolio and the bank's refinancing situation. We proxy the lending structure as the ratio of corporate loans over total nonbank loans. The funding structure is represented by total deposits over total non-bank loans.

Regional indicators. To account for regional disparities on the bank level, we include regional earnings calculated by GDP per capita in our model. Furthermore, to capture effects which may be driven by disparities in economic development after the German reunification, we control for the regional area by including a binary variable east being one when the bank is located in the former East Germany.

\subsection{Summary statistics}

This section provides descriptive statistics pertaining to the banks in our sample. We present the mean values of selected variables for the 2002 to 2006 period. We provide descriptive statistics for the full sample and different subsamples.

Table B.1 summarizes the results for the full sample. With 249 bank observations, we present the mean values of the variables for the 2002 to 2006 period. We report the bank-, regional- and market characteristics of all of the banks in our sample in column 1. In column 2 of Table B.1, we provide the means of the relevant variables for the banks 
that engage in advanced risk management. Similarly, Column 3 of Table B.1 presents the characteristics of the banks that do not use advanced risk management.

We observe from Table B.1 that differences exist across the banks that engage in advanced risk management and those that engage in more traditional risk management, despite the fact that we investigate homogeneous banks relative to their business model. From univariate inspection, we observe that in particular larger banks engage in advanced risk management. Banks net interest income and GDP per capita also differ significantly. It is also apparent that these banks have considerably higher sector concentration and less market power.

The German banking sector is known to be highly competitive. Carbo et al. (2009) estimates the average Lerner index for Germany for the period 1995 through 2001 to be 14\%, while Fernandez de Guevara et al. (2007) estimates a Lerner index between 10.63\% and $13.65 \%$ for the period 1993 through 2000. Koetter and Wedow (2010) estimates a Lerner index of 23 percent for the period 1995 through 2005, while Carbo Valverde and Rodriguez Fernandez (2007) provides a Lerner index of 35\% for the period 1994 through 2001 for the German banking sector. Fernandez de Guevara et al. (2007) show that inequalities in the levels of competition exist among the banking groups in Europe and that banks with greater traditional deposits and loan activities enjoy higher and increasing margins. Following that line of argument, it is not surprising that the estimated Lerner index for the average bank in our sample is higher than the average Lerner index of the entire German banking sector, which includes all banking groups, such as investment banks and specialized banks. The banks in our sample are active in the traditional deposit and loan business and enjoy greater market power.

[Table B.1]

Providing descriptive statistics for subsamples, we investigate the use of risk management instruments separately and show descriptive statistics for the use of credit portfolio models in Table B.2 and the use of credit transfer instruments in Table B.3.

In Table B.2 we show the mean values of the relevant variables for the whole sample of banks in column 1. In column 2 of Table B.2, we provide the means of the relevant variables for the banks that employ credit portfolio models to manage their credit portfolio and simultaneously derive business decisions from the information gathered throughout 
the process. Similarly, column 3 of Table B.1 presents the characteristics of the banks that did not internalize credit portfolio models in their bank management. We observe that larger banks are more likely to employ the credit portfolio model. Banks that integrated a credit portfolio model in their risk management framework have considerably less market power and are exposed to higher sector concentration.

[Table B.2]

In Table B.3 we compare banks that engage in credit risk transfer with banks that do not. For comparison we also report the mean values of relevant bank characteristics for all banks in column 1. From univariate inspection we observe that banks that engage in risk transfer are typcially more profitable, larger, conduct business in a more competitive environment and have been subject to mergers in the past.

[Table B.3]

Table B.4 shows the correlation between different risk strategies of banks. We distinguish between banks that employ CPM, CRT or ARM. We obsverve that ARM is correlated with both CRT and CPM. Interestingly we find that employing a credit portfolio is not necessarily correlated with the decision to engage in risk transfer markets.

[Table B.4]

Next, we present information on the number of banks that employ various risk management tools. In Table B.5 we observe that 41 banks engage in advanced risk management meaning that next to monitoring through credit portfolio models, they also derive strategies for their lending business. We observe that only a limited number of banks uses these risk management tools. Credit risk transfer instruments (CRT) and credit portfolio models (CPM) are seldom used simultaneously.

[Table B.5] 
Although we have asked banks about a wide range of risk instruments ${ }^{14}$, including traditional methods such as limit systems, we are particularly interested in CPM, CRT and the combination of the two because there is some obvious heterogeneity across banks with respect to the implementation of these advanced risk management strategies. All banks in our sample, however, implemented most of the traditional instruments.

\section{Empirical Model and Results}

\subsection{Empirical model}

The theoretical model in section 2 predicts that advanced risk management is profitable, especially if competition is high and if the sectors are concentrated. To test the implications of our theoretical model we estimate a model of the following form:

$$
\begin{aligned}
\mathrm{ARM}_{i}= & \beta_{0}+\beta_{1} \text { Net Interest Income }_{i}+\beta_{2} \text { Net Commission Income }_{i}+ \\
& \beta_{3} \text { Loan Loss Provision }_{i}+\beta_{4} \text { Equity }_{i}+\beta_{5} \text { Corporate Loan }_{i}+\beta_{6} \text { Total Asset }_{i}+ \\
& \beta_{7} \text { Deposit }_{i}+\beta_{8} \mathrm{GDP}_{i}+\beta_{9} \mathrm{HHI}_{i}+\beta_{10} \text { LERNER }_{i}+\beta_{11} \text { EAST }_{i}+\epsilon_{i}
\end{aligned}
$$

$\operatorname{ARM} i$ is the binary dependent variable indicating whether bank $i$ engages in advanced risk managemant employing both credit portfolio models (to monitor) and credit risk transfer (to diversify). $\mathrm{ARM}_{i}$ is one if the bank simultaneously uses both tools, and zero otherwise. Net Interest Income $_{i}$ is measured as net interest income over total income and net commission income ${ }_{i}$ is calculated as net non-interest income over total income. Loan

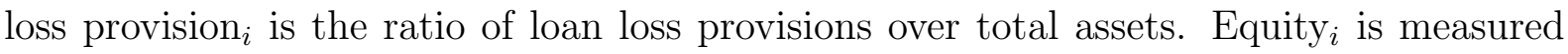
as total equity over assets. Corporate $\operatorname{Loan}_{i}$ is total corporate loans over nonbank loans.

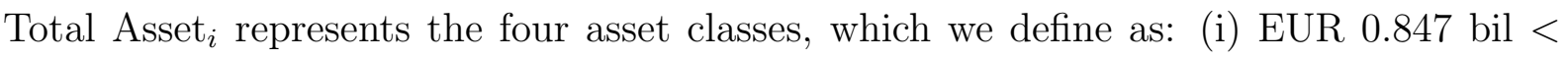
Assets < EUR 1.482 bil; (ii) EUR 1.482 bil < Assets < EUR 2.906 bil; and (iii) Assets > EUR 2.906 bil. The fourth class, assets below EUR 847 million, is the omitted category for the size indicator variables. Deposit ${ }_{i}$ is measured as deposits over the total nonbank loans. $\mathrm{GDP}_{i}$ is measured as GDP per capita on regional level. $\mathrm{HHI}_{i}$ represents the

\footnotetext{
${ }^{14} \mathrm{~A}$ detailed description of the questionnaire can be found in the appendix.
} 
portfolio concentration of the respective bank, measured by the Herfindahl-Hirschmann index for sector concentration, where the calculation is based on the number of firms conducting business by sectors in each region. LERNER $i$ is the Lerner index, a measure for market power of the respective bank and calculated in how far banks can set prices above marginal cost. EAST is a binary variable being one if the bank is located in the former East Germany, and zero otherwise. $\epsilon_{i}$ is the idiosyncratic error term ${ }^{15}$.

We reduce the panel structure of our data to a cross sectional structure since our endogenous variable for the different risk strategies does not vary over time. Thereby, we average the years 2002 to 2006 . We employ a probit regression framework to estimate the model. To account for heterogeneity among banks, we use clustered standard errors at the bank level.

In a second set of results we additionally analyze whether results remain robust if we exploit the panel structure of the data for the explanatory variables. In this model we additionaly include yearly time fixed effects.

\subsection{Results}

\subsubsection{Investigating Advanced Risk Management (ARM)}

First, we investigate what determines the decision of banks to use advanced risk management. In particular, we are interested whether banks' characteristics, regional or market conditions influence banks' decision to implement credit portfolio models to actively manage the portfolio and involve in credit risk transfer.

In Table C.6, we present the results of the probit regressions investigating banks' motivation to engage in advanced risk management. In the first column of Table C.6, we relate advanced risk management to bank characteristic variables and GDP, controlling for location of the bank (East) on the right-hand side. We find significant results for net commission income, suggesting that banks engaging heavily in non-interest income are more likely to employ advanced risk management. Banks that engage in fee-income business are very interested in profit generating activities. However, profit-generating business is often involved with higher risks that need to be managed accordingly. Thererfore, it is

\footnotetext{
${ }^{15}$ In Table C.11 in the appendix we additionally report the Pearson correlation for the explanatory variables.
} 
plausible that these banks utilize advanced risk management instruments. This finding remains robust when adding the regional and market conditions in column 2 and column 3 , as well as for the full model in the last column.

By adding regional and market characteristics to the model in column 2 and column 3 we find that competition and sector concentration are relevant for banks' decisions to engage in advance risk management. The results suggest that a marginal increase in sector concentration, as measured by the Herfindahl-Hirschman index increases the likelihood of implementing advanced instruments in banks.

A marginal increase in market power as measured by the Lerner index from the average of 0.28 results in an 71 percent decrease in the likelihood of participating in the use of sophisticated credit risk instruments. An increase in the Lerner index, which is equivalent to a diminishing level of competition, is associated with a decrease in the likelihood of involvement in advance risk management. Or put differently, higher competition leads banks to engage in advanced risk management.

\section{[Table C.6]}

Estimating our full model in column 4, we observe that both sector concentration and the level of competition influence the decision for advanced risk management for banks. These findings are in line with Khandwalla (1972) and Khandwalla (1973), who show that firms under competitive pressure use controls more extensively and more selectively.

Investigating the relationship between sector concentration and competition in the market Cetorelli and Strahan (2006) point to a potential trade-off between banking competition in the market and industry concentration. They suggest that banks are likely to restrict the market with respect to new entrants. Given increased competition through new entries, the market participants' profitability may be endangered. Thus, it is not surprising that banks influence the sector structure in the region.

Interestingly, most bank variables do not enter significantly in our model. Univariate inspection in Table B.1 already pointed to this relationship. In line with proposition 3, we find strong empirical evidence that both competition and sector concentration are positively related to advanced risk management. It appears that the depth of implementation and the integration of advanced risk management instruments are primarily influenced by competition. When we examine the separate effects of each risk management instrument, our results confirm that competition is an important driver for the decision to engage in advanced risk management instruments, which is presented in the next section. 


\subsubsection{Investigating Credit Portfolio Modeling (CPM)}

Up to this point, we have investigated banks' motivation to engage in advance risk management through the use of sophisticated risk management instruments. To acquire a better understanding of the separate effects of each risk management instrument, we investigate the use of credit portfolio models and the use of credit risk transfer instruments separately.

In Table C.7, we present the results of the probit regressions investigating the determinants of the use of credit portfolio models. In the first column of Table C.7, we relate credit portfolio management to bank characteristic variables and GDP, controlling for the location of the bank. We find that in terms of their total assets, smaller banks are less likely to engage in active credit portfolio management through the intensive use of credit portfolio models. The results do not change if we include a measure for competition in column 2 of Table C.7 and when estimating the full model in column 4. We also observe a significant effect non-interest income for all model specifications.

Adding the Lerner index to our model in column 2 and the Herfindahl index in column 3 , we observe that both measures have a significant impact on banks' decision to employ credit portfolio models, both to monitor and actively manage the portfolio. The results remain robust when we estimate the full model in column 4. Banks with less market power (higher competition) are more likely to engage in credit portfolio modeling. Furthermore, we observe that an increase in industry sector concentration measured by the Herfindahl index significantly increases the probability for banks to employ credit portfolio models to manage their portfolio. It is higher sector concentration that drives banks decision for risk management - a resuls that supports the hypothesis stated in proposition 1 of our theoretical model.

[Table C.7]

\subsubsection{Investigating Credit Risk Transfer (CRT)}

In Table C.8, we present the results of the probit regressions, investigating the determinants of the use of credit risk transfer instruments. In the first column of Table C.8 we relate the credit risk transfer to the bank characteristic variables and GDP per capita, controlling for the location of the bank. 
We observe that the lending structure of the portfolio drives banks' decision to engage in credit risk transfer markets. Banks with a higher share of corporate loans are more likely to participate in credit risk transfer markets. This is not surprising as banks with high loan business may profit most from risk transfer instruments.

In line with proposition 2, we find that banks in a more competitive environment are more likely to involve in credit risk transfer (column 2 and column 4). In contrast, sector concentration is not driving the participation decision. Yet, the sign of the coefficients is negative, as predicted by proposition 2 .

[Table C.8]

Our results provide strong empirical evidence that competition is positively related to the use of credit risk transfer instruments. It appears that a bank's decision to participate in credit risk transfer markets is mainly influenced by competition. These results empirically confirm recent research on competition and credit transfer markets. According to Hakenes and Schnabel (2010), bank competition plays an important role in the development of credit transfer markets.

\section{Further robustness tests}

In the previous section we provided the results for the probit regressions using Eq. 12 and thereby show that advanced risk management is driven by competition and sector concentration. The following provides robustness tests concerning the time structure of data, the construction of the endogenous variables and selected explanatory variables. Further, we test the robustness of our results by taking bank mergers into consideration.

\subsection{Relevance of the time structure}

In unreported results we observe that our results do not change when we conduct the analysis exploiting the panel structure of the data for the 2002 to 2006 period. We observe coefficients of similar magnitude and significance. This is not surprising given that the implementation decision for the various risk management instrumentes does not vary over time. Additionally, the averaged values on the right hand side of our model, as 
measured in Eq. 12, should serve as a good approximation of individual values over the 2002 to 2006 period. Therefore, as expected our results remain robust.

Next, we also estimate the model for each year separately for the observation period 2002-2006. In unreported results we observe that the outcomes remain robust when we estimate the model on a year to year basis.

[Table C.9]

\subsection{Relevance of bank mergers}

Bank mergers may contribute to the reduction of bank's risk through diversification (Amihud and Lev, 1981) and the utilization of scale economies (Hughes and Mester, 1998). Hughes and Mester (1998) find that larger banks have the capacity to economize on the use of financial capital. Consequently, as a bank merger is directly related to the managerial motives of the bank, it is likely to have an impact on the risk management strategy of the respective bank. Additionally, risk management strategies typically help to economize on capital, a direct consequence of mergers. To control for that issue, we include a dummy variable for a merger in our model. Repeating the analyses, we find consistent results for advanced risk management (ARM), which we report in Table C.10.

\section{[Table C.10]}

\subsection{Relevance of different proxies for bank size and the choice of CPM and CRT}

To ensure that our results for bank size are not driven by the choice of variables for size, we additionally rerun the regressions using different size proxies. In particular, we substitute the indicator variables in our main model with the number of employees and total assets. We observe that for both models, size enters significantly and positively. The results for our main explanatory variables, namely competition and sector concentration, remain robust.

Next, we are interested whether the construction of the different variables representing the risk management strategy of the bank - which is CPM, CRT and ARM - from the survey influences our results. In unreported results we find that we do not observe a significant effect if we require banks to involve in both credit risk transfer via credit pooling and 
credit derivatives. Intuitively, it does not make a lot of sense to consider a bank to be participating in credit risk transfer if the bank only conducts both diversification strategies. For a bank it is sufficient to diversify employing one of the strategies. Moreover, imposing such a strict requirement narrows our sample of participating banks to only 19 .

We imposed that a bank is considered an active user of credit portfolio models if the bank frequently monitors the credit portfolio model using any credit portfolio model available on the market and at the same time uses the information acquired to derive its business decisions. Loosening this requirement such that we also include banks that only occasionally use the model to monitor and manage in our group of participating banks, we observe that the effect diminishes. This is not surprising as occasional use implies using the model only limitedly to monitor which may restrict the impact of derived decisions.

Moroever, constructing the variable CPM from question 13-1 and 13-2 of the survey, which evaluates the type of model a certain bank employs (CPV versus other), is also not a sufficient measure for CPM. From an economic perspective this is the case because it does not matter what type of instruments a bank employs but rather whether a bank uses the model in a second step to derive business decisions from actively monitoring the portfolio. If we assign a bank to employ CPM if it implemented any model in its risk management, we observe that the results of our main analysis are confirmed. Doing so 132 banks enter sample, thus, the constructed variable is highly correlated with our main variable for CPM.

\section{Conclusion}

In this paper, we identified two major forces driving the sophistication of credit risk management, from both a theoretical and an empirical perspective: bank competition and sector concentration.

We model a bank that holds a portfolio of two risky assets. We assumed that loans can come from different industrial sectors, and if they are from the same sector, then they are perfectly correlated. By implementing a credit portfolio model, banks discover the correlation within their loan portfolios and can fine-tune their buffers or capital structures to their portfolio structures. Furthermore, banks can engage in credit risk transfer by swapping half of their loan portfolio for the loan portfolio of another bank. Through risk transfer banks can diversify their portfolios. Typically, by implementing both risk 
management instruments (advanced risk management), banks can diversify and fine-tune their portfolios.

We find that credit portfolio modeling is more desirable when competition is high; it is also more desirable for higher sector concentration. Credit risk transfer is more desirable when competition is high and more desirable for lower sector concentration. Implementing both risk management instruments, advanced risk management, is desirable when competition is high and it is also desirable for a higher sector concentration.

After deriving these results theoretically, we tested our predictions empirically on a sample of 249 banks of the German Savings Banks Finance Group. We confirm our theoretical results empirically. We find that bank competition pushes banks to implement credit portfolio models and engage in risk transfer markets. Sector concentration on the loan market promotes the decision to monitor through credit portfolio models but inhibits credit risk transfer. In this study we take the more integrated view in analyzing advanced risk management, being a combination of monitoring and diversifying efforts of the bank. As such, in this research paper we apply a more comprehensive approach to advanced risk management both theoretically and empirically.

Given that bank compeititon is continually increasing, our results may prove also valuable for regulators. We understand that the use of advanced or sophisticated risk management instruments is related to bank competition, thus, such instruments must be carefully developed and their application closely supervised. 
Acharya, V., Hasan, I., Saunders, A., 2006. Should banks be diversified? Evidence from individual bank loan portfolios. Journal of Business 79, 1355-1412.

Allen, F., Carletti, E., 2006. Credit risk transfer and contagion. Journal of Monetary Economics 53, 89-111.

Allen, F., Santomero, A., 1997. The theory of financial intermediation. Journal of Banking \& Finance 21, 1461-1485.

Altman, E. I., Saunders, A., 1998. Credit risk measurement: Developments over the last 20 years. Journal of Banking \& Finance 21, 1721-1742.

Amihud, Y., Lev, B., February 1981. Risk reduction as a managerial motive for conglomerate mergers. The Bell Journal of Economics 12 (2), 605-617.

Ashraf, D., Altunbas, Y., Goddard, J., 2007. Who transfers credit risk? Determinants of the use of credit derivatives by large U.S. banks. European Journal of Finance 13, $483-500$.

Bank for International Settlements, 2009. Risk and opportunities: Towards a fail-safe financial system. Annual Report 2008/09, 120.

Basel Committee on Banking Supervision, 2004. Bank failures in mature economies. Basel Committee on Banking Supervision, Bank for International Settlements, Working Paper 13.

Batten, J., Hogan, W., 2002. A perspective on credit derivatives. International Review of Financial Analysis 11, 251-278.

Beltratti, A., Stulz, R., 2012. The credit crisis around the globe:Why did some banks perform better? Journal of Financial Economics 105, 1-17.

Berger, A., Klapper, L., Turk-Ariss, R., 2009. Bank competition and financial stability. Journal of Financial Services Research 35, 99-118.

Bergstresser, D., 2008. Market concentration and commerical bank loan portfolios. Working Paper, Harvard Business School.

Booth, J., Smith, R., Stolz, R., 1984. The use of interest rate futures by financial institutions. Journal of Bank Research 15, 15-20. 
Boyd, J., De Nicolo, G., 2005. The theory of bank risk taking and competition revisited. Journal of Finance 60, 1329-1343.

Boyd, J., Jalal, A., 2006. Bank risk and competition: New theory and new evidence. Working Paper, International Monetary Fund 297.

Broecker, T., 1990. Credit-worthiness tests and interbank competition. Econometrica 58, $429-452$.

Brunnermeier, M., Dong, G., Palia, D., 2011. Banks' non-interest income and systemic risk. Working Paper, Princeton University.

Bülbül, D., 2013. Determinants of trust in banking networks. Journal of Economic Behavior \& Organization 85, 236-248.

C.A. Parlour, G. P., 2008. Loan sales and relationship banking. Journal of Finance 63, 1291-1314.

Carbo, S., Humphrey, D., Maudos, J., Molyneux, P., 2009. Cross-country comparisons of competition and pricing power in European banking. Journal of International Money and Finance 28, 115-134.

Carbo Valverde, S., Rodriguez Fernandez, F., 2007. The determinants of bank margins in European banking. Journal of Banking \& Finance 31, 2043-2063.

Cebenoyan, A., Strahan, P., 2004. Risk management, capital structure and lending at banks. Journal of Banking \& Finance 28, 19-43.

Cetorelli, N., Strahan, P. E., 2006. Finance as a barrier to entry: Bank competition and industry structure in local U.S. markets. Journal of Finance 61, 437-461.

Crouhy, M., Galai, D., Mark, R., 2000. A comparative analysis of current credit risk models. Journal of Banking \& Finance 24, 59-117.

Demsetz, R., 2000. Bank loan sales: A new look at the motivations for secondary market activity. Journal of Financial Research 23, 192-222.

Deutsche Bundesbank, 2006. Monthly report June.

DSGV, 2011. Inside the Savings Banks Finance Group. Published by Deutscher Sparkassen- und Giroverband (www.dsgv.de). 
Düllmann, K., Masschelein, N., 2007. A tractable model to measure sector concentration risk in credit portfolios. Journal of Financial Services Research 32, 55-79.

Ebrahim, M. S., Molyneux, P., Wilson, J. O., 2013. Financial sector performance and risk: An introduction. Journal of Economic Behavior \& Organization 85 (1), 118-121.

Fernandez de Guevara, J., Maudos, J., Perez, F., 2007. Integration and competition in the European financial markets. Journal of International Money and Finance 26, 26-45.

Flannery, M. J., S.H., K., Nimalendran, M., 2004. Market evidence on the opaqueness of banking firms' assets. Journal of Financial Economics 71, 419-460.

Froot, K., Scharfstein, D., Stein, J., 1993. Risk management: Coordinating corporate investment and financing policies. Journal of Finance 48, 1629-1658.

Gintschel, A., Hackethal, A., 2004. Multi-bank loan pool contracts: Enhancing the profitability of small commercial banks. Applied Financial Economics 14, 1239-1252.

Hakenes, H., 2004. Banks as delegated risk managers. Journal of Banking \& Finance 28, 2399-2426.

Hakenes, H., Schnabel, I., 2010. Credit risk transfer and bank competition. Journal of Financial Intermediation 19, 308-332.

Hellmann, T., Murdock, K., Stiglitz, J., 2000. Liberalization,moral hazard in banking, and prudential regulation: Are capital requirements enough? American Economic Review 90, 147-165.

Hellwig, M., February 2010. Capital regulation after the crisis. business as usual? MPI Preprint 31.

Hughes, J. P., Mester, L. J., February 1998. Bank capitalization and cost: Evidence of scale economies. Review of Economics and Statistics 80 (2), 314-325.

Ibragimov, R., Jaffee, D., Walden, J., 2012. Originate-to-distribute model and the subprime mortgage crisis. Journal of Financial Economics 99, 333-348.

Jiménez, G., Lopez, J., Saurina, J., 2010. How does competition impact bank risk taking? Working paper, Banco de Espana. 
Joint Forum, 2008. Cross-sectoral review of group-wide identification and management of risk concentrations. Basel Committee on Banking Supervision, Bank for International Settlements.

Keeley, M., 1990. Deposit insurance, risk and market power in banking. American Economic Review 80, 1183-1200.

Khandwalla, P. N., 1972. The effect of different types of competition on the use of management controls. Journal of Accounting Research 10, 275-285.

Khandwalla, P. N., 1973. Effect of competition on the structure of top management control. Academy of Management Journal of Banking \& Finance 16, 285-295.

Kim, S., Koppenhaver, G., 1993. An empirical analysis of bank interest-rate swaps. Journal of Financial Services Research 7, 57-74.

Koetter, M., Wedow, M., 2010. Finance and growth in a bank-based economy: Is it quantity or quality that matters? Journal of International Money and Finance 29, $1529-1545$.

Krahnen, J. P., Schmidt, R. (Eds.), 2004. The German Financial System. Oxford University Press.

Krause, A., Giansante, S., 2012. Interbank lending and the spread of bank failures: A network model of systemic risk. Journal of Economic Behavior \& Organization 83 (3), $583-608$.

Memmel, C., Schmieder, C., Stein, I., 2007. Relationship banking: Empirical evidence for Germany. Discussion Paper Series 2: Banking and Financial Studies, Deutsche Bundesbank, Research Centre, 1-34.

Minton, B., Stulz, R., Williamson, R., 2009. How much do banks use credit derivatives to hedge loans? Journal of Financial Services Research 35, 1-31.

Moody's, 2010. Credit analysis - Sparkassen-Finanzgruppe. Global Banking.

Morgan, D., 2002. Rating banks: risk and uncertainty in a opaque industry. American Economic Review 88, 874-888.

Moser, S., Soukup, K., 2002. State guarantees to German public banks: a new step in the enforcement of state aid discipline to financial services in the community. European Commission, Competition Policy Newsletter 2. 
Office of the Comptroller of the Currency, 2009. OCC's quarterly report on bank trading and derivatives activities, third quarter 2009. Washington, DC 20219.

URL http://www.occ.treas.gov

Pennacchi, G., 1988. Loan sales and the cost of bank capital. Journal of Finance 43, $375-396$.

Puri, M., Rocholl, J., Steffen, S., 2011. Global retail lending in the aftermath of the us financial crisis: Distinguishing between supply and demand effects. Journal of Financial Economics 100 (3), 556-578.

Purnanandam, A., 2011. Originate-to-distribute model and the subprime mortgage crisis. Review of Financial Studies 24, 1881-1915.

Santomero, A., 1997. Commercial bank risk management: An anlysis of the process. Journal of Financial Services Research 12, 83-115.

Schmidt, R. H., 2009. The political debate about savings banks. Schmalenbach Business Review 61, 366-392.

Senior Supervisors Group, 2008. Observations on risk management practices during the recent market turbulence.

Sinkey, J., Carter, D., 2000. Evidence on the financial characteristics of banks that do and do not use derivatives. Quarterly Review of Economics and Finance 40, 431-449.

Stein, J., 2002. Information production and capital allocation: Decentralized versus hierarchical firms. Journal of Finance 57, 1891-1921.

Stultz, R., 1984. Optimal hedging policies. Journal of Financial and Quantitative Analysis 19.

Wagner, W., 2010. Diversification at financial institutions and systemic crises. Journal of Financial Intermediation 19, 373-386. 


\section{Appendix A. Survey structure}

The survey was conducted in 2009. The full questionnaire was 10 pages long (including cover). The questionnaire was accompanied by explanatory cover letters from the CEO of the German Savings Banks Association and the academic project team, which assured the confidentiality of the responses. Each questionnaire was printed with the name and address of the bank to allow the responding banks' characteristics to be identified and match with other data sources. The front page included general instructions for completion and the definitions of the terms used in the questionnaire.

The respondents were asked to provide information about the instruments used in their daily corporate business to manage credit risk. We differentiate between the credit risk instruments used to measure credit risk and those used to actively manage credit risk.

The dependent variables are constructed from Question 12 and Question 13 of the questionnaire. The participants indicate the usage intensity of the instruments as frequently, occasionally or no use.

Question 12: Which of the following instruments are used to manage credit risk in daily corporate business?

1- Internal risk limits on exposure to particular obligor names

2 - Internal risk limits on exposure to industry sectors

3 - Internal risk limits on exposure to asset classes

4- Syndicated loans with Landesbank

5 - Syndicated loans with the neighbor savings bank

6- Guaranteed loans by Landesbank

7- Guaranteed loans by other Institutions

8- Loan sales

9- Bonded loans with Landesbank

10- Credit risk transfer (credit pooling)

11- Credit risk transfer (credit derivatives)

12- Other (please list other used instruments if applicable)

\section{Question 13: Credit portfolio modeling.}

1- How intensively does your bank use the credit portfolio model "CreditPortfolioView (CPV)" to analyse credit portfolio risk?

2 - How intensively does your bank use other credit portfolio models to analyse credit portfolio risk?

3 - How intensively does your bank use the results from quantitative credit portfolio analyses (CPV, other) for active management of the credit portfolio?

Original German Questions. Frage 12: Welche der folgenden Instrumente zur Steuerung von Kreditrisiken werden in Ihrer Sparkasse eingesetzt?

1- Einhaltung von vorgegebenen Kreditrisikolimits im Hinblick auf eine Kreditvolumenbegrenzung 
2- Einhaltung von vorgegebenen Kreditrisikolimits im Hinblick auf Branchenlimits

3- Einhaltung von vorgegebenen Kreditrisikolimits im Hinblick auf eine Größenklassenstruktur

4- Konsortialkreditgeschäfte mit Landesbanken (Barbeteiligung)

5- Konsortialkreditgeschäfte mit Nachbarsparkassen

6- Avalierung durch Landesbanken (Ausfallbürgschaften, Haftungsbeteiligung)

7- Avalierung durch Drittinstitute wie z.B. Bürgschaftsbanken (Ausfallbürgschaft)

8- Verkauf von Kreditforderungen

9- Vermittlung von Firmenkrediten an Landesbanken (Schuldscheindarlehen)

10- Kreditpooling (Basket-Transaktionen)

11- Kreditderivate (Einzelkreditabsicherung z.B. über Credit Default Swaps, S-Port)

12- Andere (bitte angeben welche)

\section{Frage 13: Kreditportfoliomodell.}

1- Wie intensiv nutzt Ihre Sparkasse das Kreditportfoliomodell "Credit Portfolio View" (CPV) zur Analyse der Risiken im Kreditportfolio?

2- Wie intensiv nutzt Ihre Sparkasse andere Kreditportfoliomodelle zur Analyse der Risiken im Kreditportfolio?

3- Mit welcher Intensität verwendet Ihre Sparkasse die Ergebnisse aus der quantitativen Kreditportfolioanalyse (CPV, andere) zur aktiven Steuerung des Kreditportfolios?

\section{Appendix B. Descriptive Tables}


Table B.1: Summary Statistics and differences in means (ARM)

This table shows the mean values for banks' characteristics, market measures and regional characteristics, averaged for the 2002 to 2006 period for all banks in column 1. In column 2 characteristics are reported for ARM users. Mean values for banks that do not employ ARM are presented in column 3 . In column 4 we test for comparison of means between the two groups. Net Interest Income is standardized over total income. Net Commission Income is net commission income over total income. Loan Loss Provisions are standardized over total assets. Asset 1 is the following size indicator variable: EUR 0.847 bil < Assets < EUR 1.482 bil. Asset 2 is the following size indicator variable: EUR 1.482 bil < Assets < EUR 2.906 bil. Asset 3 is the following size indicator variable: Assets > EUR 2.906 bil. Equity is banks' common equity standardized over total assets. Corporate Loans are standardized over non-bank loans. Deposits represents the funding side of banks' balance sheet and are standardized over non-bank loans. EAST is a binary variable, amounting to 1 if the bank is located in the former East Germany, and zero otherwise. GDP is measured as GDP over capita. HHI is the Herfindahl index for sector concentration and LERNER measures in how far banks can set prices over marginal $G D P$ is measured as GDP over capita. HHI is the Herfindahl index for sector concent
costs. *,**, and ${ }^{* * *}$ indicate significance at the $10 \%, 5 \%$ and $1 \%$ levels, respectively.

\begin{tabular}{|c|c|c|c|c|c|c|c|c|}
\hline & \multicolumn{2}{|c|}{ (1) All banks } & \multicolumn{2}{|c|}{ (2) ARM Users } & \multicolumn{2}{|c|}{ (3) ARM Non-Users } & \multirow[b]{2}{*}{ Difference } & \multirow[b]{2}{*}{ p-values } \\
\hline & mean & sd & mean & sd & mean & sd & & \\
\hline Net Interest income & 0.4263 & 0.0352 & 0.4092 & 0.0334 & 0.4276 & 0.0351 & $0.0184^{*}$ & $(2.15)$ \\
\hline Net Commission Income & 0.0997 & 0.0162 & 0.1032 & 0.0097 & 0.0994 & 0.0166 & -0.00383 & $(-0.97)$ \\
\hline Loan Loss Provision & 0.0206 & 0.0095 & 0.0225 & 0.0083 & 0.0204 & 0.0096 & -0.00204 & $(-0.87)$ \\
\hline Asset 1 & 0.2958 & 0.5051 & 0.1364 & 0.3970 & 0.3082 & 0.5112 & 0.172 & $(1.39)$ \\
\hline Asset 2 & 0.5093 & 0.8710 & 0.4954 & 0.8816 & 0.5104 & 0.8721 & 0.0150 & $(0.07)$ \\
\hline Asset 3 & 1.5164 & 3.4961 & 4.3048 & 4.8307 & 1.2991 & 3.2862 & $-3.006^{* * *}$ & $(-3.60)$ \\
\hline Corporate Loans & 0.3127 & 0.0652 & 0.3162 & 0.0684 & 0.3124 & 0.0651 & -0.00382 & $(-0.24)$ \\
\hline Equity & 0.0469 & 0.0088 & 0.0441 & 0.0054 & 0.0472 & 0.0090 & 0.00309 & $(1.43)$ \\
\hline Deposits & 0.5583 & 0.2320 & 0.5527 & 0.2945 & 0.5588 & 0.2272 & 0.00611 & $(0.11)$ \\
\hline EAST & 0.1165 & 0.3214 & 0.1111 & 0.3234 & 0.1169 & 0.3220 & 0.00577 & $(0.07)$ \\
\hline GDP & 24.2590 & 7.7944 & 30.6938 & 16.8464 & 23.7576 & 6.4060 & $-6.936^{* * *}$ & $(-3.73)$ \\
\hline HHI & 0.1583 & 0.0133 & 0.1692 & 0.0146 & 0.1574 & 0.0128 & $-0.0118^{* * *}$ & $(-3.73)$ \\
\hline LERNER & 0.2861 & 0.0711 & 0.2189 & 0.0622 & 0.2913 & 0.0692 & $0.0724^{* * *}$ & $(4.31)$ \\
\hline Total Assets & 14.2482 & 0.9369 & 15.0644 & 0.9066 & 14.1846 & 0.9108 & $-0.880^{* * *}$ & $(-3.95)$ \\
\hline No. Employees & 459.8781 & 474.4064 & 861.0739 & 525.1171 & 428.6161 & 456.8537 & $-432.5^{* * *}$ & $(-3.83)$ \\
\hline Merger & 0.3293 & 0.4709 & 0.4444 & 0.5113 & 0.3203 & 0.4676 & -0.124 & $(-1.08)$ \\
\hline Observations & 249 & & 18 & & 231 & & & \\
\hline
\end{tabular}


Table B.2: Summary Statistics and differences in means (CPM)

This table shows the mean values for banks' characteristics, market measures and regional characteristics, averaged for the 2002 to 2006 period for all banks in column 1. In column 2 characteristics are reported for ARM users. Mean values for banks that do not employ ARM are presented in column 3 . In column 4 we test for comparison of means between the two groups. Net Interest Income is standardized over total income. Net Commission Income is net commission income over total income. Loan Loss Provisions are standardized over total assets. Asset 1 is the following size indicator variable: EUR 0.847 bil < Assets < EUR 1.482 bil. Asset 2 is the following size indicator variable: EUR 1.482 bil < Assets < EUR 2.906 bil. Asset 3 is the following size indicator variable: Assets > EUR 2.906 bil. Equity is costs. ${ }^{*}, * *$, and $* * *$ indicate significance at the $10 \%, 5 \%$ and $1 \%$ levels, respectively.

\begin{tabular}{|c|c|c|c|c|c|c|c|c|}
\hline & \multicolumn{2}{|c|}{ (1) All banks } & \multicolumn{2}{|c|}{ (2) CPM Users } & \multicolumn{2}{|c|}{ (3) CPM Non-Users } & \multirow[b]{2}{*}{ Difference } & \multirow[b]{2}{*}{ p-value } \\
\hline & mean & sd & mean & sd & mean & sd & & \\
\hline Net Interest income & 0.4263 & 0.0352 & 0.4167 & 0.0305 & 0.4281 & 0.0359 & 0.0114 & $(1.91)$ \\
\hline Net Commission Income & 0.0997 & 0.0162 & 0.1038 & 0.0124 & 0.0988 & 0.0167 & -0.00501 & $(-1.82)$ \\
\hline Loan Loss Provision & 0.0206 & 0.0095 & 0.0221 & 0.0083 & 0.0203 & 0.0097 & -0.00183 & $(-1.13)$ \\
\hline Asset 1 & 0.2958 & 0.5051 & 0.1089 & 0.3385 & 0.3326 & 0.5246 & $0.224^{* *}$ & $(2.62)$ \\
\hline Asset 2 & 0.5093 & 0.8710 & 0.6454 & 0.9624 & 0.4825 & 0.8518 & -0.163 & $(-1.09)$ \\
\hline Asset 3 & 1.5164 & 3.4961 & 2.9813 & 4.0306 & 1.2276 & 3.3160 & $-1.754^{* *}$ & $(-2.98)$ \\
\hline Corporate Loans & 0.3127 & 0.0652 & 0.3168 & 0.0593 & 0.3118 & 0.0664 & -0.00497 & $(-0.45)$ \\
\hline Equity & 0.0469 & 0.0088 & 0.0460 & 0.0083 & 0.0471 & 0.0089 & 0.00118 & $(0.78)$ \\
\hline Deposits & 0.5583 & 0.2320 & 0.5458 & 0.3023 & 0.5608 & 0.2163 & 0.0150 & $(0.38)$ \\
\hline EAST & 0.1165 & 0.3214 & 0.1220 & 0.3313 & 0.1154 & 0.3203 & -0.00657 & $(-0.12)$ \\
\hline GDP & 24.2590 & 7.7944 & 27.1312 & 12.1808 & 23.6929 & 6.4929 & $-3.438^{* *}$ & $(-2.61)$ \\
\hline HHI & 0.1583 & 0.0133 & 0.1657 & 0.0162 & 0.1568 & 0.0122 & $-0.00889^{* * *}$ & $(-4.03)$ \\
\hline LERNER & 0.2861 & 0.0711 & 0.2469 & 0.0739 & 0.2938 & 0.0681 & $0.0469^{* * *}$ & (3.98) \\
\hline Total Assets & 14.2482 & 0.9369 & 14.7221 & 1.0246 & 14.1548 & 0.8920 & $-0.567^{* * *}$ & $(-3.63)$ \\
\hline No. Employees & 459.8781 & 474.4064 & 687.0227 & 493.8885 & 415.1045 & 458.5518 & $-271.9^{* * *}$ & $(-3.43)$ \\
\hline Merger & 0.3293 & 0.4709 & 0.4390 & 0.5024 & 0.3077 & 0.4627 & -0.131 & $(-1.64)$ \\
\hline Observations & 249 & & 41 & & 208 & & & \\
\hline
\end{tabular}


Table B.3: Summary Statistics and differences in means (CRT)

This table shows the mean values for banks' characteristics, market measures and regional characteristics, averaged for the 2002 to 2006 period for all banks in column 1. In column 2 characteristics are reported for ARM users. Mean values for banks that do not employ ARM are presented in column 3 . In column 4 we test for comparison of means between the two groups. Net Interest Income is standardized over total income. Net Commission Income is net commission income over total income. Loan Loss Provisions are standardized over total assets. Asset 1 is the following size indicator variable: EUR 0.847 bil < Assets < EUR 1.482 bil. Asset 2 is the following size indicator variable: EUR 1.482 bil < Assets i EUR 2.906 bil. Asset 3 is the following size indicator variable: Assets > EUR 2.906 bil. Equity is banks' common equity standardized over total assets. Corporate Loans are standardized over non-bank loans. Deposits represents the funding side of banks' balance sheet and are standardized over non-bank loans. $E A S T$ is a binary variable, amounting to 1 if the bank is located in the former East Germany and zero otherwise. GDP is measured as GDP over capita. HHI is the Herfindahl index for sector concentration and LERNER measures in how far banks can set prices over marginal costs. *, **, and $* * *$ indicate significance at the $10 \%, 5 \%$ and $1 \%$ levels, respectively.

\begin{tabular}{|c|c|c|c|c|c|c|c|c|}
\hline & \multicolumn{2}{|c|}{ (1) All banks } & \multicolumn{2}{|c|}{ (2) CRT Users } & \multicolumn{2}{|c|}{ (3) CRT Non-Users } & \multirow[b]{2}{*}{ Difference } & \multirow[b]{2}{*}{ p-values } \\
\hline & mean & sd & mean & sd & mean & sd & & \\
\hline Net Interest income & 0.4263 & 0.0352 & 0.4166 & 0.0305 & 0.4315 & 0.0366 & $0.0150^{* *}$ & $(3.26)$ \\
\hline Net Commission Income & 0.0997 & 0.0162 & 0.1002 & 0.0150 & 0.0994 & 0.0168 & -0.000777 & $(-0.36)$ \\
\hline Loan Loss Provision & 0.0206 & 0.0095 & 0.0224 & 0.0087 & 0.0195 & 0.0098 & $-0.00288^{*}$ & $(-2.30)$ \\
\hline Asset 1 & 0.2958 & 0.5051 & 0.2195 & 0.4507 & 0.3375 & 0.5292 & 0.118 & $(1.77)$ \\
\hline Asset 2 & 0.5093 & 0.8710 & 0.5350 & 0.8627 & 0.4953 & 0.8779 & -0.0397 & $(-0.34)$ \\
\hline Asset 3 & 1.5164 & 3.4961 & 2.9272 & 4.9718 & 0.7452 & 1.9523 & $-2.182^{* * *}$ & $(-4.92)$ \\
\hline Corporate Loans & 0.3127 & 0.0652 & 0.3332 & 0.0678 & 0.3015 & 0.0610 & $-0.0317^{* * *}$ & $(-3.77)$ \\
\hline Equity & 0.0469 & 0.0088 & 0.0458 & 0.0079 & 0.0476 & 0.0093 & 0.00180 & $(1.54)$ \\
\hline Deposits & 0.5583 & 0.2320 & 0.5326 & 0.2031 & 0.5724 & 0.2459 & 0.0398 & $(1.30)$ \\
\hline EAST & 0.1165 & 0.3214 & 0.1136 & 0.3192 & 0.1180 & 0.3236 & 0.00438 & $(0.10)$ \\
\hline GDP & 24.2590 & 7.7944 & 26.4233 & 10.8798 & 23.0760 & 5.0811 & $-3.347^{* *}$ & $(-3.30)$ \\
\hline $\mathrm{HHI}$ & 0.1583 & 0.0133 & 0.1597 & 0.0152 & 0.1575 & 0.0121 & -0.00225 & $(-1.28)$ \\
\hline LERNER & 0.2861 & 0.0711 & 0.2541 & 0.0727 & 0.3035 & 0.0640 & $0.0494^{* * *}$ & $(5.55)$ \\
\hline Total Assets & 14.2482 & 0.9369 & 14.6905 & 0.9116 & 14.0065 & 0.8616 & $-0.684^{* * *}$ & $(-5.87)$ \\
\hline No. Employees & 459.8781 & 474.4064 & 662.4841 & 630.5190 & 349.1370 & 312.6625 & $-313.3^{* * *}$ & $(-5.24)$ \\
\hline Merger & 0.3293 & 0.4709 & 0.4091 & 0.4945 & 0.2857 & 0.4532 & $-0.123^{*}$ & $(-1.99)$ \\
\hline Observations & 249 & & 88 & & 161 & & & \\
\hline
\end{tabular}


Table B.4: Pearson correlations of dependent variables

Table B.4 shows the correlation matrix of the different risk management instruments the banks employ. ${ }^{*},{ }^{* *}$, and ${ }^{* * *}$ indicate significance at the $10 \%, 5 \%$ and $1 \%$ levels, respectively.

\begin{tabular}{lccc}
\hline & CRT & CPM & ARM \\
\hline CRT & 1 & & \\
CPM & 0.0795 & 1 & \\
ARM & $0.378^{* * *}$ & $0.629^{* * *}$ & 1 \\
\hline
\end{tabular}

Table B.5: Number of Banks

Table B.5 presents the number of banks using the different risk management instruments.

\begin{tabular}{lcc}
\hline Instruments & Usage & Non-Usage \\
\hline Credit Portfolio Models (CPM) & 41 & 208 \\
Credit Risk Transfer (CRT) & 88 & 161 \\
CRT and CPM (ARM) & 18 & 231 \\
\hline
\end{tabular}

Appendix C. Result Tables 
Table C.6: Advanced Risk Management (ARM)

This table shows results for regressions of Eq. (12) with ARM as the dependent variable. The dependent variable is a binary variable, taking the value of one if the bank implements ARM, and zero otherwise. Net Interest Income is standardized over total income. Net Commission Income is net commission income over total income. Loan Loss Provisions are standardized over total assets. Assets below EUR 847 million is the omitted category for the size indicator variables. Equity is banks' common equity standardized over total assets. Equity is banks' common equity standardized over total assets. Corporate Loans are standardized over non-bank loans. Deposits represents the funding side of banks' balance sheet and is standardized over non-bank loans. EAST is a binary variable, amounting to one if the bank is located in the former East Germany and zero otherwise. GDP is measured as GDP over capita. HHI is the Herfindahl index for sector concentration and LERNER measures in how far banks can set prices over marginal costs. We report the marginal effects. ${ }^{*}, * *$, and $* * *$ indicate significance at the $10 \%, 5 \%$ and $1 \%$ levels, respectively.

\begin{tabular}{lcccc}
\hline Variable & $(\mathbf{1})$ & $(\mathbf{2})$ & $(\mathbf{3})$ & $(\mathbf{4})$ \\
\hline Net Interest Income & ARM & ARM & ARM & ARM \\
Net Commission Income & -0.5139 & -0.2260 & -0.6286 & -0.3154 \\
& $(0.5071)$ & $(0.4315)$ & $(0.4590)$ & $(0.4103)$ \\
Loan Loss Provision & $2.1267^{* *}$ & $1.7518^{* *}$ & $2.0945^{* *}$ & $1.6958^{* *}$ \\
& $(0.8914)$ & $(0.7934)$ & $(0.8165)$ & $(0.7278)$ \\
EUR 0.847 bil < Assets < EUR 1.482 bil & 0.8824 & 0.0140 & 0.5335 & -0.1898 \\
& $(1.6456)$ & $(1.5015)$ & $(1.4693)$ & $(1.3638)$ \\
EUR 1.482 bil < Assets < EUR 2.906 bil & -0.0233 & -0.0223 & -0.0124 & -0.0135 \\
& $(0.0333)$ & $(0.0274)$ & $(0.0306)$ & $(0.0255)$ \\
Assets > EUR 2.906 bil & 0.0090 & -0.0068 & 0.0136 & -0.0021 \\
& $(0.0157)$ & $(0.0132)$ & $(0.0145)$ & $(0.0127)$ \\
Corporate Loans & 0.0055 & -0.0032 & 0.0023 & -0.0048 \\
& $(0.0038)$ & $(0.0036)$ & $(0.0035)$ & $(0.0037)$ \\
Equity & -0.0823 & -0.1402 & 0.0790 & -0.0082 \\
& $(0.2056)$ & $(0.1858)$ & $(0.1942)$ & $(0.1711)$ \\
Deposits & -1.3347 & -0.6725 & -0.6516 & -0.2122 \\
& $(1.9506)$ & $(1.7208)$ & $(1.7664)$ & $(1.5875)$ \\
EAST & 0.0690 & 0.0207 & 0.0925 & 0.0475 \\
& $(0.0856)$ & $(0.0744)$ & $(0.0807)$ & $(0.0721)$ \\
GDP & $-0.0525^{*}$ & -0.0188 & -0.0420 & -0.0128 \\
& $(0.0314)$ & $(0.0518)$ & $(0.0340)$ & $(0.0552)$ \\
HHI & 0.0021 & 0.0015 & 0.0004 & 0.0003 \\
& $(0.0014)$ & $(0.0011)$ & $(0.0014)$ & $(0.0011)$ \\
LERNER & & & $2.6505^{* *}$ & $1.9286^{*}$ \\
& & & $(1.1268)$ & $(1.0101)$ \\
ps. R-squared & & $-0.7155^{* * *}$ & & $-0.6390^{* * *}$ \\
log pseudolikelihood & $(0.2532)$ & & $(0.2451)$ \\
Wald & & & & \\
\hline
\end{tabular}


Table C.7: Credit Portfolio Management (CPM)

This table shows results for regressions of Eq. (12) with CPM as the dependent variable. The dependent variable is a binary variable, taking the value of one if the bank implements CPM, and zero otherwise. Net Interest Income is standardized over total income. Net Commission Income is net commission income over total income. Loan Loss Provisions are standardized over total assets. Assets below EUR 847 million is the omitted category for the size indicator variables. Equity is banks' common equity standardized over total assets. Corporate Loans are standardized over non-bank loans. Deposits represents the funding side of banks' balance sheet and is standardized over non-bank loans. EAST is a binary variable, amounting to one if the bank is located in the former East Germany and zero otherwise. GDP is measured as GDP over capita. HHI is the Herfindahl index for sector concentration and LERNER measures in how far banks can set prices over marginal costs. We report the marginal effects. ${ }^{*},{ }^{* *}$, and ${ }^{* * *}$ indicate significance at the $10 \%, 5 \%$ and $1 \%$ levels, respectively.

\begin{tabular}{lcccc}
\hline Variable & $(\mathbf{1})$ & $\mathbf{( 2 )}$ & $\mathbf{( 3 )}$ & $\mathbf{( 4 )}$ \\
\hline Net Interest income & $\mathbf{C P M}$ & $\mathbf{C P M}$ & $\mathbf{C P M}$ & $\mathbf{C P M}$ \\
& -1.2153 & -0.9890 & $-1.4639^{*}$ & -1.2248 \\
Net Commission Income & $(0.8038)$ & $(0.8153)$ & $(0.8085)$ & $(0.8323)$ \\
& $5.2114^{* * *}$ & $4.9050^{* * *}$ & $5.7081^{* * *}$ & $5.3918^{* * *}$ \\
Loan Loss Provision & $(1.5403)$ & $(1.5226)$ & $(1.5206)$ & $(1.5177)$ \\
& 1.7005 & 0.6426 & 0.9692 & 0.0750 \\
EUR 0.847 bil < Assets $<$ EUR 1.482 bil & $(2.5738)$ & $(2.6533)$ & $(2.4409)$ & $(2.5773)$ \\
& $-0.1060^{*}$ & $-0.1233^{* *}$ & -0.0854 & $-0.1027^{*}$ \\
EUR 1.482 bil < Assets $<$ EUR 2.906 bil & $(0.0567)$ & $(0.0555)$ & $(0.0552)$ & $(0.0546)$ \\
& 0.0318 & -0.0028 & 0.0405 & 0.0092 \\
Assets $>$ EUR 2.906 bil & $(0.0271)$ & $(0.0286)$ & $(0.0267)$ & $(0.0276)$ \\
Corporate Loans & 0.0105 & -0.0043 & 0.0022 & -0.0104 \\
& $(0.0073)$ & $(0.0084)$ & $(0.0066)$ & $(0.0085)$ \\
Equity & -0.1827 & -0.2262 & 0.2644 & 0.2092 \\
Deposits & $(0.3441)$ & $(0.3485)$ & $(0.3216)$ & $(0.3218)$ \\
& 1.3073 & 2.2987 & 2.4243 & 3.1947 \\
EAST & $(3.1622)$ & $(3.1740)$ & $(2.9881)$ & $(3.0277)$ \\
& 0.0197 & -0.0383 & 0.0869 & 0.0353 \\
GDP & $(0.1463)$ & $(0.1475)$ & $(0.1409)$ & $(0.1422)$ \\
& -0.0653 & 0.0143 & -0.0418 & 0.0305 \\
HHI & $(0.0950)$ & $(0.1428)$ & $(0.1031)$ & $(0.1477)$ \\
& 0.0024 & 0.0022 & -0.0018 & -0.0016 \\
LERNER & $(0.0027)$ & $(0.0026)$ & $(0.0028)$ & $(0.0027)$ \\
& & & $7.0485^{* * *}$ & $6.6468^{* * *}$ \\
ps. R-squared & & & $(2.0539)$ & $(2.0396)$ \\
log pseudolikelihood & & $-1.1028^{* *}$ & & $-0.9500^{*}$ \\
Wald & & $(0.5008)$ & & $(0.4955)$ \\
\hline
\end{tabular}


Table C.8: Credit Risk Transfer (CRT)

This table shows results for regressions of Eq. (12) with CRT as the dependent variable. The dependent variable is a binary variable, taking the value of one if the bank implements CRT, and zero otherwise. Net Interest Income is standardized over total income. Net Commission Income is net commission income over total income. Loan Loss Provisions are standardized over total assets. Assets below EUR 847 million is the omitted category for the size indicator variables. Equity is banks' common equity standardized over total assets. Corporate Loans are standardized over non-bank loans. Deposits represents the funding side of banks' balance sheet and is standardized over non-bank loans. EAST is a binary variable, amounting to one if the bank is located in the former East Germany and zero otherwise. GDP is measured as GDP over capita. HHI is the Herfindahl index for sector concentration and LERNER measures in how far banks can set prices over marginal costs. We report the marginal effects. ${ }^{*}, * *$, and $* * *$ indicate significance at the $10 \%, 5 \%$ and $1 \%$ levels, respectively.

\begin{tabular}{|c|c|c|c|c|}
\hline Variable & $\begin{array}{l}(1) \\
\text { CRT }\end{array}$ & $\begin{array}{l}(2) \\
\text { CRT }\end{array}$ & $\begin{array}{l}(3) \\
\text { CRT }\end{array}$ & $\begin{array}{l}(4) \\
\text { CRT }\end{array}$ \\
\hline Net Interest income & $\begin{array}{l}-1.5000 \\
(1.2470)\end{array}$ & $\begin{array}{l}-1.2186 \\
(1.2682)\end{array}$ & $\begin{array}{l}-1.4097 \\
(1.2584)\end{array}$ & $\begin{array}{l}-1.1392 \\
(1.2760)\end{array}$ \\
\hline Net Commission Income & $\begin{array}{c}3.2358 \\
(2.4734)\end{array}$ & $\begin{array}{c}2.4334 \\
(2.5296)\end{array}$ & $\begin{array}{c}3.0400 \\
(2.4981)\end{array}$ & $\begin{array}{c}2.2770 \\
(2.5510)\end{array}$ \\
\hline Loan Loss Provision & $\begin{array}{c}2.1884 \\
(3.8036)\end{array}$ & $\begin{array}{c}1.0674 \\
(3.8307)\end{array}$ & $\begin{array}{c}2.3323 \\
(3.8089)\end{array}$ & $\begin{array}{l}1.2228 \\
(3.8376)\end{array}$ \\
\hline EUR 0.847 bil < Assets < EUR 1.482 bil & $\begin{array}{c}0.0198 \\
(0.0730)\end{array}$ & $\begin{array}{l}-0.0428 \\
(0.0750)\end{array}$ & $\begin{array}{c}0.0158 \\
(0.0738)\end{array}$ & $\begin{array}{l}-0.0473 \\
(0.0762)\end{array}$ \\
\hline EUR 1.482 bil < Assets < EUR 2.906 bil & $\begin{array}{l}0.0595 \\
(0.0412)\end{array}$ & $\begin{array}{l}-0.0082 \\
(0.0481)\end{array}$ & $\begin{array}{l}0.0570 \\
(0.0412)\end{array}$ & $\begin{array}{l}-0.0106 \\
(0.0487)\end{array}$ \\
\hline Assets $>$ EUR 2.906 bil & $\begin{array}{c}0.0498^{* * *} \\
(0.0169)\end{array}$ & $\begin{array}{c}0.0143 \\
(0.0181)\end{array}$ & $\begin{array}{c}0.0544^{* * * *} \\
(0.0180)\end{array}$ & $\begin{array}{c}0.0182 \\
(0.0197)\end{array}$ \\
\hline Corporate Loans & $\begin{array}{l}1.2902^{* *} \\
(0.5337)\end{array}$ & $\begin{array}{l}1.3050^{* *} \\
(0.5256)\end{array}$ & $\begin{array}{l}1.1388^{* *} \\
(0.5458)\end{array}$ & $\begin{array}{l}1.1692^{* *} \\
(0.5385)\end{array}$ \\
\hline Equity & $\begin{array}{l}-1.4615 \\
(4.5794)\end{array}$ & $\begin{array}{l}-0.1054 \\
(4.6311)\end{array}$ & $\begin{array}{l}-1.7111 \\
(4.6174)\end{array}$ & $\begin{array}{c}-0.3573 \\
(4.6702)\end{array}$ \\
\hline Deposits & $\begin{array}{c}-0.1435 \\
(0.2037)\end{array}$ & $\begin{array}{c}-0.2016 \\
(0.2076)\end{array}$ & $\begin{array}{c}-0.1720 \\
(0.2069)\end{array}$ & $\begin{array}{c}-0.2269 \\
(0.2082)\end{array}$ \\
\hline EAST & $\begin{array}{c}0.0383 \\
(0.1887)\end{array}$ & $\begin{array}{c}0.1926 \\
(0.2105)\end{array}$ & $\begin{array}{c}0.0309 \\
(0.1873)\end{array}$ & $\begin{array}{c}0.1839 \\
(0.2100)\end{array}$ \\
\hline GDP & $\begin{array}{c}0.0048 \\
(0.0053)\end{array}$ & $\begin{array}{c}0.0055 \\
(0.0048)\end{array}$ & $\begin{array}{c}0.0066 \\
(0.0057)\end{array}$ & $\begin{array}{c}0.0072 \\
(0.0052)\end{array}$ \\
\hline HHI & & & $\begin{array}{l}-2.8710 \\
(3.1629)\end{array}$ & $\begin{array}{l}-2.5886 \\
(3.1910)\end{array}$ \\
\hline LERNER & & $\begin{array}{c}-1.6221^{* *} \\
(0.7535)\end{array}$ & & $\begin{array}{c}-1.6112^{* *} \\
(0.7605)\end{array}$ \\
\hline ps. R-squared & 0.1372 & 0.1480 & 0.1395 & 0.1499 \\
\hline log pseudolikelihood & -139.5446 & -137.7967 & -139.1675 & -137.4870 \\
\hline Wald & 33.2753 & 44.2411 & 33.1521 & 44.9236 \\
\hline $\mathrm{N}$ & 249 & 249 & 249 & 249 \\
\hline
\end{tabular}


Table C.9: Sensitivity Analyses - Size

This table shows results for regressions of Eq. (12) with ARM, CPM and CRT as the dependent variable. The dependent variable is a binary variable, taking the value of one if the bank implements the respective risk management strategy, and zero otherwise. Net Interest Income is standardized over total income. Net Commission Income is net commission income over total income. Loan Loss Provisions are standardized over total assets. Size is measured as No. Employees, the number of employees and Total assets, which is the log of banks' total assets. Equity is banks' common equity standardized over total assets. Corporate Loans are standardized over non-bank loans. Deposits represents the funding side of banks' balance sheet and is standardized over non-bank loans. EAST is a binary variable, amounting to one if the bank is located in the former East Germany and zero otherwise. GDP is measured as GDP over capita. HHI is the Herfindahl index for sector concentration and LERNER measures in how far banks can set prices over marginal costs. We report the marginal effects. *, **, and *** indicate significance at the $10 \%, 5 \%$ and $1 \%$ levels, respectively.

\begin{tabular}{|c|c|c|c|c|c|c|}
\hline Variable & \multicolumn{2}{|c|}{$\mathrm{ARM}$} & \multicolumn{2}{|c|}{ CPM } & \multicolumn{2}{|c|}{ CRT } \\
\hline Net Interest income & $\begin{array}{c}-0.2504 \\
(0.4432)\end{array}$ & $\begin{array}{c}-0.2673 \\
(0.4188)\end{array}$ & $\begin{array}{c}-0.9479 \\
(0.8984)\end{array}$ & $\begin{array}{c}-1.0677 \\
(0.8917)\end{array}$ & $\begin{array}{l}-1.5411 \\
(1.2741)\end{array}$ & $\begin{array}{c}-1.2314 \\
(1.2729)\end{array}$ \\
\hline Net Commission Income & $\begin{array}{c}1.9302^{* *} \\
(0.7940)\end{array}$ & $\begin{array}{c}1.7374^{* *} \\
(0.7542)\end{array}$ & $\begin{array}{c}5.4491^{* * *} \\
(1.5819)\end{array}$ & $\begin{array}{c}5.5796^{* * *} \\
(1.5804)\end{array}$ & $\begin{array}{c}3.4598 \\
(2.6219)\end{array}$ & $\begin{array}{c}2.0733 \\
(2.5730)\end{array}$ \\
\hline Loan Loss Provision & $\begin{array}{c}0.0977 \\
(1.4680)\end{array}$ & $\begin{array}{c}-0.2372 \\
(1.3843)\end{array}$ & $\begin{array}{c}0.1884 \\
(2.6112)\end{array}$ & $\begin{array}{l}-0.2761 \\
(2.6525)\end{array}$ & $\begin{array}{c}0.4574 \\
(3.7592)\end{array}$ & $\begin{array}{c}0.6980 \\
(3.8417)\end{array}$ \\
\hline Total Assets & $\begin{array}{c}0.0021 \\
(0.0299)\end{array}$ & & $\begin{array}{l}-0.0269 \\
(0.0553)\end{array}$ & & $\begin{array}{c}0.1692^{* *} \\
(0.0856)\end{array}$ & \\
\hline No. Employees & & $\begin{array}{l}-0.0000 \\
(0.0000)\end{array}$ & & $\begin{array}{l}-0.0001 \\
(0.0001)\end{array}$ & & $\begin{array}{c}0.0001 \\
(0.0001)\end{array}$ \\
\hline Corporate Loans & $\begin{array}{c}-0.0226 \\
(0.1836)\end{array}$ & $\begin{array}{c}0.0124 \\
(0.1725)\end{array}$ & $\begin{array}{c}0.2558 \\
(0.3427)\end{array}$ & $\begin{array}{c}0.3107 \\
(0.3379)\end{array}$ & $\begin{array}{c}1.1321^{* *} \\
(0.5391)\end{array}$ & $\begin{array}{c}1.1775^{* *} \\
(0.5389)\end{array}$ \\
\hline Equity & $\begin{array}{l}-0.5788 \\
(1.5844)\end{array}$ & $\begin{array}{l}-0.1540 \\
(1.5933)\end{array}$ & $\begin{array}{c}2.6471 \\
(3.1872)\end{array}$ & $\begin{array}{c}2.9375 \\
(3.1642)\end{array}$ & $\begin{array}{l}-2.0287 \\
(4.6229)\end{array}$ & $\begin{array}{l}-0.9291 \\
(4.6590)\end{array}$ \\
\hline Deposits & $\begin{array}{c}0.0498 \\
(0.0759)\end{array}$ & $\begin{array}{c}0.0476 \\
(0.0707)\end{array}$ & $\begin{array}{c}0.0153 \\
(0.1474)\end{array}$ & $\begin{array}{c}0.0178 \\
(0.1447)\end{array}$ & $\begin{array}{l}-0.2093 \\
(0.2036)\end{array}$ & $\begin{array}{l}-0.2364 \\
(0.2067)\end{array}$ \\
\hline EAST & $\begin{array}{l}-0.0316 \\
(0.0363)\end{array}$ & $\begin{array}{l}-0.0090 \\
(0.0613)\end{array}$ & $\begin{array}{c}0.0068 \\
(0.1396)\end{array}$ & $\begin{array}{c}0.0373 \\
(0.1506)\end{array}$ & $\begin{array}{c}0.0795 \\
(0.2064)\end{array}$ & $\begin{array}{c}0.1813 \\
(0.2134)\end{array}$ \\
\hline GDP & $\begin{array}{l}-0.0000 \\
(0.0012)\end{array}$ & $\begin{array}{c}0.0001 \\
(0.0011)\end{array}$ & $\begin{array}{l}-0.0025 \\
(0.0029)\end{array}$ & $\begin{array}{c}-0.0022 \\
(0.0028)\end{array}$ & $\begin{array}{c}0.0079 \\
(0.0050)\end{array}$ & $\begin{array}{c}0.0077 \\
(0.0050)\end{array}$ \\
\hline HHI & $\begin{array}{l}1.7122^{*} \\
(1.0089)\end{array}$ & $\begin{array}{c}2.0040^{* *} \\
(1.0115)\end{array}$ & $\begin{array}{c}6.4872^{* * *} \\
(2.0137)\end{array}$ & $\begin{array}{c}7.0350^{* * *} \\
(2.0776)\end{array}$ & $\begin{array}{l}-2.3040 \\
(3.1092)\end{array}$ & $\begin{array}{l}-1.8913 \\
(3.1955)\end{array}$ \\
\hline LERNER & $\begin{array}{l}-0.4895 \\
(0.4006)\end{array}$ & $\begin{array}{c}-0.7174^{* * *} \\
(0.2568)\end{array}$ & $\begin{array}{l}-1.1459 \\
(0.7338)\end{array}$ & $\begin{array}{c}-1.2641^{* *} \\
(0.6143)\end{array}$ & $\begin{array}{l}-0.1022 \\
(1.1069)\end{array}$ & $\begin{array}{c}-1.4115^{*} \\
(0.8127)\end{array}$ \\
\hline ps. R-squared & 0.2139 & 0.2238 & 0.1528 & 0.1580 & 0.1547 & 0.1458 \\
\hline log pseudolikelihood & -50.7965 & -50.1609 & -94.3652 & -93.7848 & -136.7098 & -138.1581 \\
\hline Wald & 39.6613 & 37.6558 & 31.0849 & 29.4177 & 45.1358 & 43.8838 \\
\hline $\mathrm{N}$ & 249 & 249 & 249 & 249 & 249 & 249 \\
\hline
\end{tabular}


Table C.10: Sensitivity Analyses - Bank Merger

This table shows results for regressions of Eq. (12) with ARM, CPM and CRT as the dependent variable. The dependent variable is a binary variable, taking the value of one if the bank implements the respective risk management strategy, and zero otherwise. Net Interest Income is standardized over total income. Net Commission Income is net commission income over total income. Loan Loss Provisions are standardized over total assets. Assets below EUR 847 million is the omitted category for the size indicator variables. Equity is banks' common equity standardized over total assets. Corporate Loans are standardized over non-bank loans. Deposits represents the funding side of banks' balance sheet and is standardized over non-bank loans. EAST is a binary variable, amounting to one if the bank is located in the former East Germany and zero otherwise. GDP is measured as GDP over capita. Merger is a binary variable, amounting to 1 of the bank was involved in a merger, and zero otherwise. HHI is the Herfindahl index for sector concentration and LERNER measures in how far banks can set prices over marginal costs. We report the marginal effects. ${ }^{*}, * *$, and ${ }^{* * *}$ indicate significance at the $10 \%, 5 \%$ and $1 \%$ levels, respectively.

\begin{tabular}{lccc}
\hline & ARM & CPM & CRT \\
\hline Net Interest income & -0.3238 & -1.2248 & -1.1062 \\
Net Commission Income & $(0.4160)$ & $(0.8323)$ & $(1.2828)$ \\
& $1.6959^{* *}$ & $5.3918^{* * *}$ & 2.2689 \\
Loan Loss Provision & $(0.7303)$ & $(1.5177)$ & $(2.5480)$ \\
& -0.2536 & 0.0750 & 1.3631 \\
EUR 0.847 bil < Assets < EUR 1.482 bil & $(1.4064)$ & $(2.5773)$ & $(3.8587)$ \\
EUR 1.482 bil < Assets < EUR 2.906 bil & -0.0123 & $-0.1027^{*}$ & -0.0501 \\
& $(0.0250)$ & $(0.0546)$ & $(0.0758)$ \\
Assets > EUR 2.906 bil & -0.0017 & 0.0092 & -0.0108 \\
& $(0.0123)$ & $(0.0276)$ & $(0.0486)$ \\
Corporate Loans & -0.0048 & -0.0104 & 0.0180 \\
& $(0.0037)$ & $(0.0085)$ & $(0.0195)$ \\
Equity & -0.0097 & 0.2092 & $1.1749^{* *}$ \\
& $(0.1708)$ & $(0.3218)$ & $(0.5386)$ \\
Deposits & -0.2752 & 3.1947 & -0.1614 \\
EAST & $(1.6290)$ & $(3.0277)$ & $(4.7016)$ \\
GDP & 0.0473 & 0.0353 & -0.2265 \\
& $(0.0718)$ & $(0.1422)$ & $(0.2083)$ \\
Merger & -0.0148 & 0.0305 & 0.1961 \\
HHI & $(0.0524)$ & $(0.1477)$ & $(0.2121)$ \\
& 0.0004 & -0.0016 & 0.0071 \\
LERNER & $(0.0011)$ & $(0.0027)$ & $(0.0052)$ \\
& 0.0061 & & -0.0257 \\
ps. R-squared & $(0.0255)$ & & $(0.0759)$ \\
log pseudolikelihood & $1.9705^{*}$ & $6.6468^{* * *}$ & -2.7162 \\
Wald & $(1.0062)$ & $(2.0396)$ & $(3.2166)$ \\
& $-0.6174^{* *}$ & $-0.9500^{*}$ & $-1.7049^{* *}$ \\
& $(0.2543)$ & $(0.4955)$ & $(0.8035)$ \\
\hline
\end{tabular}


Table C.11: Pearson correlations of explanatory variables

This table shows reports the Person correlations for all explanatory variables. Net Interest Income is standardized over total income. Net Commission Income is net commission income

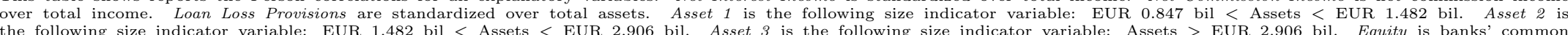

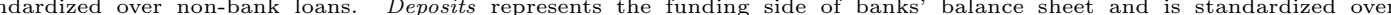
non-bank loans. EAST is a binary variable, amounting to 1 if the bank is located in the former East Germany and zero otherwise. GDP is measured as GDP over capita. HHI is the Herfindahl index for sector concentration and $L E R N E R$ measures in how far banks can set prices over marginal costs. $* * *$, , and $* * *$ indicate significance at the $10 \%, 5 \%$ and $1 \%$ levels, respectively.

\begin{tabular}{|c|c|c|c|c|c|c|c|c|c|c|c|c|c|c|c|c|}
\hline & NIM & $\mathrm{NCI}$ & LLP & Asset 1 & Asset 2 & Asset 3 & Corp & Equity & Dep & EAST & GDP & $\mathrm{HHI}$ & LERNER & TAs & Employees & Merger \\
\hline NIM & & & & & & & & & & & & & & & & \\
\hline NCI & $0.309^{* * * *}$ & $\frac{1}{1}$ & & & & & & & & & & & & & & \\
\hline $\begin{array}{l}\text { LLP } \\
\text { Asset } 1\end{array}$ & $\begin{array}{r}-0.0746 \\
0.104\end{array}$ & $\begin{array}{l}0.225^{* * * *} \\
0.127^{*}\end{array}$ & 1 & & & & & & & & & & & & & \\
\hline $\begin{array}{l}\text { Asset } 1 \\
\text { Asset 2 }\end{array}$ & $\begin{array}{c}0.104 \\
0.0231\end{array}$ & $\begin{array}{c}0.127^{*} \\
-0.0221\end{array}$ & $\begin{array}{c}0.0525 \\
0.102\end{array}$ & $\begin{array}{c}1 \\
-0 \\
308 * * *\end{array}$ & & & & & & & & & & & & \\
\hline $\begin{array}{l}\text { Asset 2 } \\
\text { Asset 3 }\end{array}$ & $\begin{array}{c}0.0231 \\
-0.289 * * *\end{array}$ & $\begin{array}{l}-0.0221 \\
-0.0903\end{array}$ & $\begin{array}{c}0.102 \\
0.0489\end{array}$ & $\begin{array}{l}-0.308 * \pi \\
-0.255^{* * *}\end{array}$ & $\begin{array}{c}1 \\
-0.239 * * *\end{array}$ & 1 & & & & & & & & & & \\
\hline Corp & $\begin{array}{l}-0.285 \\
-0.153^{*}\end{array}$ & $\begin{array}{l}-0.0905 \\
-0.0244\end{array}$ & & $\begin{array}{l}-0.250 \\
-0.0273\end{array}$ & 0.0967 & $\begin{array}{c}1 \\
0.113\end{array}$ & 1 & & & & & & & & & \\
\hline Equity & $0.237 * * *$ & $\begin{array}{l}-0.0244 * \\
-0.167 * *\end{array}$ & $\begin{array}{l}0.240 \\
-0.315^{* * *}\end{array}$ & $\begin{array}{l}-0.0273 \\
0.0861\end{array}$ & $\begin{array}{r}0.0967 \\
-0.0242\end{array}$ & $\begin{array}{r}0.113 \\
-0.107\end{array}$ & $\begin{array}{c}1 \\
0.0103\end{array}$ & 1 & & & & & & & & \\
\hline $\begin{array}{l}\text { Dep } \\
\text { Dep }\end{array}$ & $0.500^{* * *}$ & $0.405^{* * * *}$ & $\begin{array}{l}-0.0535 \\
0.0535\end{array}$ & $\begin{array}{l}0.0801 \\
0.0987\end{array}$ & $\begin{array}{c}-0.0242 \\
0.0268\end{array}$ & $\begin{array}{l}-0.101 \\
-0.0794\end{array}$ & $\begin{array}{l}0.0103 \\
-0.116\end{array}$ & $\begin{array}{l}0.199^{* *} \\
-\end{array}$ & 1 & & & & & & & \\
\hline EAST & $0.402^{* * *}$ & $0.597^{* * *}$ & $0.339^{* * *}$ & 0.103 & -0.00956 & -0.0350 & -0.0411 & $-0.417^{* * *}$ & $0.640 * * *$ & 1 & & & & & & \\
\hline GDP & $-0.335^{* * *}$ & $-0.155^{*}$ & 0.0158 & $-0.149^{*}$ & -0.111 & $0.459^{* * *}$ & 0.0705 & -0.00117 & $-0.219^{* * *}$ & $-0.271^{* * *}$ & 1 & & & & & \\
\hline HHI & $-0.213 * * *$ & $-0.239 * * *$ & -0.0616 & $-0.213^{* * *}$ & $-0.182^{* *}$ & $0.472^{* * *}$ & $-0.170 * *$ & -0.0111 & $-0.230^{* * *}$ & $-0.242^{* * *}$ & $0.519^{* * *}$ & 1 & & & & \\
\hline LERNER & $0.372^{* * *}$ & 0.0960 & $-0.149^{*}$ & $0.141^{*}$ & $-0.217^{* * * *}$ & $-0.619^{* * * *}$ & $-0.175 * *$ & 0.105 & 0.111 & $0.202^{* *}$ & $-0.335 * * *$ & $-0.258^{* * *}$ & & & & \\
\hline $\mathrm{TA}$ & $-0.235 * * *$ & -0.0609 & $0.179^{* *}$ & $-0.156^{*}$ & $0.187^{* *}$ & $0.730^{* * *}$ & $0.195^{* *}$ & -0.0835 & -0.00157 & -0.00573 & $0.316^{* * *}$ & $0.301^{* * *}$ & $-0.874^{* * *}$ & 1 & & \\
\hline Employees & $-0.234^{* * *}$ & -0.0156 & 0.113 & $-0.241 * * *$ & -0.0206 & $0.951 * * *$ & $0.158^{*}$ & -0.105 & -0.0000452 & 0.0226 & $0.385 * * *$ & $0.397^{* * *}$ & $-0.750 * * *$ & $0.849^{* * *}$ & 1 & \\
\hline Merger & 0.100 & $0.175 * *$ & $0.236^{* * *}$ & -0.0713 & $0.179^{* *}$ & $0.208 * * *$ & $0.148^{*}$ & -0.0559 & $0.200^{* *}$ & $0.252^{* * * *}$ & -0.0938 & -0.124 & $-0.363^{* * *}$ & $0.370^{* * *}$ & $0.334^{* * *}$ & 1 \\
\hline
\end{tabular}




\section{Appendix D. Proofs}

Proof of Proposition 1 (CPM). In the benchmark case without CPM and, therefore, without further information on the correlation structure, the optimal buffer $k^{*}$ is given by the first order condition (4), thus

$$
\frac{c}{2 \sqrt{2 \pi} \sigma}\left(\rho^{2} e^{-\frac{\left(2-k^{*}-2 R\right)^{2}}{8 \sigma^{2}}}+\sqrt{2}\left(1-\rho^{2}\right) e^{-\frac{\left(2-k^{*}-2 R\right)^{2}}{4 \sigma^{2}}}\right)=\phi k^{*}
$$

The r.h.s. is positive but decreasing in $k^{*}$, the l.h.s. is increasing and starts in the origin, hence the solution to (D.1) is unique and strictly positive. With CPM, the bank knows whether it is in the correlated situation (probability $\rho^{2}$ ), in which case the buffer $k_{1}^{*}$ is defined by (6), thus

$$
\frac{c}{2 \sqrt{2 \pi} \sigma} e^{-\frac{\left(2-k^{*}-2 R\right)^{2}}{8 \sigma^{2}}}=\phi k_{1}^{*}
$$

For the reason stated above, the solution for $k_{1}^{*}$ is unique and strictly positive. If the bank is in the uncorrelated situation (probability $1-\rho^{2}$ ) the buffer $k_{0}^{*}$ is defined by (7),

$$
\frac{c}{2 \sqrt{2 \pi} \sigma} \sqrt{2} e^{-\frac{\left(2-k^{*}-2 R\right)^{2}}{4 \sigma^{2}}}=\phi k_{0}^{*}
$$

again with unique and strictly positive solution for $k_{0}^{*}$. Because (D.1) is a convex combination of (D.2) and (D.3), the solution must then be between, $k_{0}^{*}<k^{*}<k_{1}^{*}$. By implementing CPM, if the bank obtains a negative information (probability $\rho^{2}$ ), it increases its buffer from $k^{*} t o k_{1}^{*}$, otherwise, it reduces the buffer to $k_{0}^{*}$.

Let us now discuss some comparative statics. The r. h.s. of all three of the above equations defines bell-shaped curves with the modal point at $k=2-2 R$, which is negative because the $R>1$. As $R$ increases, the bell moves right, so the intersection $k^{*}$ (or $k_{1}^{*}$ or $k_{2}^{*}$ ) decreases. In the limit $R \rightarrow \infty$, the buffer drops to $k^{*} \rightarrow 0$ (and $k_{1}^{*} \rightarrow 0$ and $k_{2}^{*} \rightarrow 0$ ). Consequently, the larger $R$, the smaller the difference between the buffer levels $k_{1}^{*}-k^{*}$ and $k^{*}-k_{0}^{*}$. Due to the convex (quadratic) shape of $c(k)=\phi k^{2} / 2$, the saving of costs depends on the difference between optimal buffer levels. Thus, as $R$ increases, the benefit of CPM is reduced. In the limit of $R \rightarrow \infty$, the benefit of CPM converges to zero. This is visible in Figure 2.

Next consider a change in $\rho$. The values of $k_{0}^{*}$ and $k_{1}^{*}$ do not depend on $\rho$, but $k^{*}$ increases in $\rho$, with $\left.k^{*}\right|_{\rho=0}=k_{0}^{*}$ and $\left.k^{*}\right|_{\rho=1}=k_{1}^{*}$. As a direct consequence, CPM bears zero benefit 
in the extreme cases $\rho=0$ and $\rho=1$, and the benefit is strictly positive in between. Because the benefit is smooth in $\rho$, it must increase in $\rho$ for small $\rho$. This is also visible in Figure 2.

Proof of Proposition 2 (CRT). As argued in the main text, if the bank makes use of credit risk transfer, there are four possible constellations for the correlation structure. Aggregate expected profits are

$$
\begin{aligned}
\Pi_{\mathrm{CRT}} & =2 R-2-\phi k^{2} / 2-c\left[\rho^{4} \Phi\left(\frac{2-k-2 R}{2 \sigma}\right)+4 \rho^{3}(1-\rho) \Phi\left(\frac{2-k-2 R}{\sqrt{5 / 2} \sigma}\right)\right. \\
& \left.+6 \rho^{2}(1-\rho)^{2} \Phi\left(\frac{2-k-2 R}{\sqrt{3 / 2} \sigma}\right)+(3 \rho+1)\left(1-\rho^{3}\right) \Phi\left(\frac{2-k-2 R}{\sigma}\right)\right]
\end{aligned}
$$

The first order condition is

$$
\frac{c}{\sigma \sqrt{\pi}}\left[\rho^{4} \frac{X^{8 / 8}}{\sqrt{8}}+\rho^{3}(1-\rho) \frac{X^{8 / 5}}{\sqrt{5}}+6 \rho^{2}(1-\rho)^{2} \frac{X^{8 / 3}}{\sqrt{3}}+(3 \rho+1)\left(1-\rho^{3}\right) \frac{X^{8 / 2}}{\sqrt{2}}\right]=\phi k^{*},
$$

with $X$ defined by (4). Again, the r. h.s. defines a bell-shaped curve with modal point at $k=2-2 R<0$, and the l.h. s. is an increasing straight line through the origin, hence the intersection point $k^{*}$ is unique and strictly positive. Next, addressing the comparative statics, with the same argument as in proposition $1, \partial k^{*} / \partial R<0$ with in the extreme $k^{*} \rightarrow 0$ for $R \rightarrow \infty$. In addition, the PDs in the four constellations converges to zero. The benefit of diversification (CRT) decreases in $R$, and converges to zero in the limit. This is visible in Figure 3.

The argument for an increase in $\rho$ proceeds differently. For a small $\rho$, only the fourth constellation applies, thus,

$$
\begin{aligned}
\Pi_{\mathrm{CRT}} & \approx 2 R-2-\phi k^{2} / 2-c \Phi\left(\frac{2-k-2 R}{\sigma}\right) \text { and } \\
\phi k^{*} & \approx \frac{c}{\sigma \sqrt{\pi}} \frac{X^{8 / 2}}{\sqrt{2}} .
\end{aligned}
$$

With $\rho \approx 0$, the diversification through CRT is maximal with probability 1 . Hence, the reduction in the bank's PD is maximal, in addition, the bank will reduce the buffer $k$ more than with any other $\rho$. Consequently, the benefit is maximal for $\rho=0$. Because the benefit is smooth in $\rho$, it must decrease in $\rho$ for a small $\rho$. Both properties are visible in Figure 3. 
Proof of Proposition 3 (ARM). Under ARM, the bank transfers credit risk and diversifies (CRT), in addition, it gathers information on correlations (CPM). There are four constellations. Let us index them as 4, 3, 2 and 1, according to the maximal number of correlated loans in the portfolio. Constellation 4 occurs with ex ante probability $\rho^{4}$. Profit function and first order condition are

$$
\begin{aligned}
\Pi_{\mathrm{ARM}} & =2 R-2-\phi k_{4}^{2} / 2-c \Phi\left(\frac{2-k_{4}-2 R}{2 \sigma}\right) \quad \text { and } \\
\phi k_{4}^{*} & =\frac{c}{\sigma \sqrt{\pi}} \frac{e^{-\frac{\left(2-k_{4}^{*}-2 R\right)^{2}}{8 \sigma^{2}}}}{\sqrt{8}} .
\end{aligned}
$$

The implicit functions defining the optimal buffer levels in the other three scenarios have similar structures, we omit them here to avoid clutter. In equilibrium, $k_{4}^{*}>k_{3}^{*}>k_{2}^{*}>k_{1}^{*}$, and the buffer level of a bank using only CRT is between the extremes, $k_{4}^{*}>k^{*}>k_{1}^{*}$. Here, the argument that an increase in $R$ renders ARM less beneficial is the same as in the two proofs above. Therefore, let us turn to a change in $\rho$. Note that to implement ARM, it must be more beneficial than the best alternative, CPM or CRT. Then for a small $\rho$, we know that CPM is not much better than the benchmark case, whereas the benefits of CRT in comparison with the benchmark are maximized. Therefore, to complete the proof, we need to consider the value added by ARM when compared with CRT. For $\rho \approx 0$, the additional benefit then vanishes. With probability 1 , all four loans are mutually independent. Therefore, because the benefit is smooth in $\rho$, it must increase in $\rho$ for a small $\rho$. This is also visible in Figure 4. 